\title{
Association of predators and prey at frontal features in the California Current: competition, facilitation, and co-occurrence
}

\author{
David G. Ainley ${ }^{1, *}$, Katie D. Dugger ${ }^{2}$, R. Glenn Ford ${ }^{3}$, Stephen D. Pierce ${ }^{4}$, \\ Douglas C. Reese ${ }^{2}$, Richard D. Brodeur ${ }^{5}$, Cynthia T. Tynan ${ }^{6}$, John A. Barth ${ }^{4}$ \\ ${ }^{1}$ H.T. Harvey \& Associates, 983 University Ave., Bldg D, Los Gatos, California 95032, USA \\ ${ }^{2}$ Department of Fisheries \& Wildlife, Oregon State University, 104 Nash Hall, Corvallis, Oregon 97331, USA \\ ${ }^{3}$ R.G. Ford Consulting, 2735 NE Weidler St., Portland, Oregon 97232, USA \\ ${ }^{4}$ College of Oceanic \& Atmospheric Sciences, Oregon State University, Corvallis, Oregon 97331, USA \\ ${ }^{5}$ NOAA Fisheries, Northwest Fisheries Science Center, Newport, Oregon 97365, USA \\ ${ }^{6}$ Associated Scientists of Woods Hole, PO Box 438, West Falmouth, Massachusetts 02578, USA
}

\begin{abstract}
We investigated variations in the small- to meso-scale abundance and distribution of the 6 most abundant seabird species in the northern California Current - black-footed albatross Phoebastria nigripes, sooty shearwater Puffinus griseus, pink-footed shearwater Puffinus creatopus, forktailed storm-petrel Oceanodroma furcata, common murre Uria aalge, and Cassin's auklet Ptychoramphus aleuticus - during the upwelling season of 2000 and 2002. Covariates (21 total), with importance assessed using logistic and generalized linear modeling and an information theoretic approach, included physical features such as sea surface temperature, dynamic height (apparent water-column pressure), and pycnocline depth; biological factors such as chlorophyll maximum; and food-web factors such as the density of 3 size classes of zooplankton, the density of potential piscine competitors, i.e. Pacific salmon Oncorhynchus spp., and abundance of fish prey such as zooplankton, northern anchovy Engraulis mordax, and the juveniles of salmon and demersal fishes. The most important factors explaining seabird occurrence changed from mesoscale physical features during a food-rich year (2002; exhibited over 15 to $30 \mathrm{~km}$ ) to smaller-scale occurrence of actual prey patches during a food-poor year $\left(2000_{;}<1 \mathrm{~km}\right)$. Spatial overlap in occurrence of murres and shearwaters with adult salmon was interpreted as co-occurrence and, perhaps, competition for prey species; a negative spatial overlap between shearwaters and abundance of forage fish was interpreted as evidence for prey depletion (or predator-induced alteration of availability) by the birds and other co-occurring predators (salmon). Overall, results and other information indicated the value of adding spatially explicit data on predator and prey species abundance and predator-prey behavior to improve foodweb modeling.
\end{abstract}

KEY WORDS: California Current · Food-web modeling · Prey depletion · Salmon · Seabird · Trophic competition $\cdot$ Upwelling fronts $\cdot$ Hotspots

\section{INTRODUCTION}

Models of marine food webs have made remarkable progress in recent years, partly by mining a wealth of information painstakingly accumulated over past decades on species' abundance, productivity, and diet. These models can now be used to summarize information and assess the potential for trophic interactions, including food-web alterations by anthropogenic influence. They are also very useful in identifying important gaps in our knowledge as we work toward an understanding of how open-ocean food webs work. A recent attempt to model 
the marine food web of the eastern Bering Sea was accomplished by Trites et al. (1999), who noted that their modeling (using in part ECOSIM and ECOPATH) was incapable of satisfactorily incorporating spatial aspects and especially that of foraging by mobile top predators. Similarly, food web models for the northern California Current (NCC; Field et al. 2006, Ruzicka et al. 2007), which incorporate biomass and trophic interactions of higher trophic levels, also appear to be poorly resolved in the spatial domain. Most recently, the spatially explicit modeling of Brand et al. (2007) has made significant progress in this regard.

Having better spatial resolution within an ecological setting characterized by the addition and subtraction of species, such as in the case of the NCC, allows better explanation of time- and space-varying predator and prey interactions. These models use the so-called efficiencies or rates of outcome of trophic interactions to assess and quantify energy flow. Lacking still in these models, however, is the degree to which the rate of energy and resource transfer among trophic levels is dependent upon or facilitated or inhibited by such processes as competition or symbiosis (see, e.g. Lima \& Dill 1990, Alonzo 2002, Lima 2002, Alonzo et al. 2003, Fiksen et al. 2005). Models thus far largely incorporate the net predation or consumption aspect of ecological interactions. Addressing the behavioral aspects of predation in ecosystem models, however, would be important in determining, for instance, how changes in physical forcing, e.g. a climate regime shift, could affect ecosystem organization beyond merely altering its basic carrying capacity or food-web structure if the abundance of keystone or strongly interacting species is altered (e.g. Soulé et al. 2005). Repercussions would cascade up and down the trophic pyramid, especially if frontal or 'hotspot' structures had become altered in location and intensity; already limited in space, this is where predators or the act of predation itself concentrates prey (e.g. Hoefer 2000, Reese \& Brodeur 2006).

The accumulation of information on the spatial and ecological aspects of species interactions requires atsea research in which species' abundance can be measured simultaneously at multiple spatial and temporal scales. Co-occurrence in 3-dimensional space and time would be the first hint at the potential for interaction among species. Modern technology has been advancing rapidly to accommodate this need through the use of towed or autonomous multi-sensing arrays that provide a continuous record of ocean and food-web properties at various depths. The ability to apply these data to biological interactions in the middle and upper trophic levels of ecosystems, however, is still in a developmental stage.

We had the opportunity to investigate those biophysical ocean properties that have the strongest effect on the mesoscale $(\sim 15 \mathrm{~km}$, and finer scale) density of seabirds by using towed multi-beam acoustic and SeaSoar arrays in the Northeast Pacific GLOBEC program (see Batchelder et al. 2002, 2005). This program was designed to better understand trophic interactions in the NCC. In a preliminary look at these data, we were able to investigate the effects of physical environmental factors on the density of seabird species during a single year (Ainley et al. 2005). Since then we have derived actual abundance estimates of potential prey of various sizes from the original acoustic data and from trawls of fish - potential seabird prey and competitors - conducted closely in time and space to the SeaSoar and acoustic effort. Finally, we have also added data from additional cruises in an oceanographically different year, and one characterized by significantly altered prey abundances. Herein we present results of this statistical modeling effort designed to determine the most important environmental covariates for the 6 most abundant avian species over multiple years to better understand structure in the upper portions of the NCC food web. We hypothesized that by including estimates of prey abundance, the importance of physical proxies for this factor, which were evident in the initial analysis (Ainley et al. 2005), would subside significantly, and also that we could reduce the measurement of relationships to below the mesoscale.

\section{MATERIALS AND METHODS}

We conducted 4 surveys to explore seasonal and interannual patterns of community interactions in the context of upwelling dynamics in the NCC. We sampled during the onset of upwelling in early summer (29 May to 11 June 2000 and 1 to 18 June 2002; hereafter called June 2000 and June 2002 cruises, respectively) and during the mature phase of upwelling in late summer (29 July to 12 August 2000 and 1 to $17 \mathrm{Au}$ gust 2002; hereafter called August 2000 and August 2002 cruises, respectively). The study area extended from Newport, Oregon $\left(44.6^{\circ} \mathrm{N}\right)$, south to Crescent City, California $\left(41.9^{\circ} \mathrm{N}\right)$, from the coast to $150 \mathrm{~km}$ offshore. Three vessels were involved in each sampling period: 1 continuously towing SeaSoar and acoustic arrays, 1 conducting day-night MOCNESS sampling of zooplankton, and 1 trawling for small pelagic fish. The towed-array vessel traversed regular grid lines, while the other vessels conducted their net tows either just before or just after that vessel passed in order to maintain spatial and temporal cohesion of sampling.

The towed-array vessel surveyed a grid of 12 'mesoscale' track lines approximately 15 nautical miles (n miles; $27 \mathrm{~km}$ ) apart, and 2 grids of embedded 'fine- 
scale' track lines $7.5 \mathrm{n}$ miles $(13.5 \mathrm{~km})$ in the northern and southern portions of the larger (mesoscale) GLOBEC-NCC area (Fig. 1). The MOCNESS vessel mostly followed these tracks as well, sampling at predetermined intervals. A chartered fishing vessel deployed midwater trawls located 1, 5, 10, 15, 20, 25, and $30 \mathrm{n}$ miles from shore along several of the designated transects and at fine-scale sampling stations. Both net-towing vessels also sampled in areas of particular physical and/or biological interest (e.g. hotspots and/or areas associated with fronts or eddies). During 2000, seabird surveys, described below, were conducted from the RV 'New Horizon', which attempted to closely follow the RV 'Wecoma', from which the arrays were towed. RV 'New Horizon' was charged mainly with the task of conducting MOCNESS tows, but since its cruising speed was greater than that of the RV 'Wecoma' (slowed in its towing capacity), it was able to keep up.

Although continuously-underway sampling is more suitable to seabird surveys, we could not observe from
RV 'Wecoma' due to lack of berthing space and because the ship's stacks, being forward of the bridge, would have partially blocked our view. For a given area of ocean, most seabird data were collected from RV 'New Horizon' often in tandem and mostly within $12 \mathrm{~h}$, but never more than $24 \mathrm{~h}$ from collection of the SeaSoar and acoustic data (described in 'Data collection'). We did not view this as an acute problem owing to the NCC's spatio-temporal coherence scales. As indicated by Barth et al. (2000), the offshore (depth $>100 \mathrm{~m}$ ) meanders in the region last for weeks to months. Inshore (depth $<100 \mathrm{~m}$ ), currents throughout the water column and surface temperature and salinity change with the wind forcing on 2 to $10 \mathrm{~d}$ time scales. The deeper ( $\sim 50 \mathrm{~m})$ horizontal density, temperature, and salinity fronts are more stable. In general, alongshore correlation length scales are much longer than cross-shelf correlation length scales. For instance, Kundu \& Allen (1976), using moored-array velocity data, found alongshore and cross-shelf correlation scales of at least $30 \mathrm{~km}$, i.e. about the same distance as
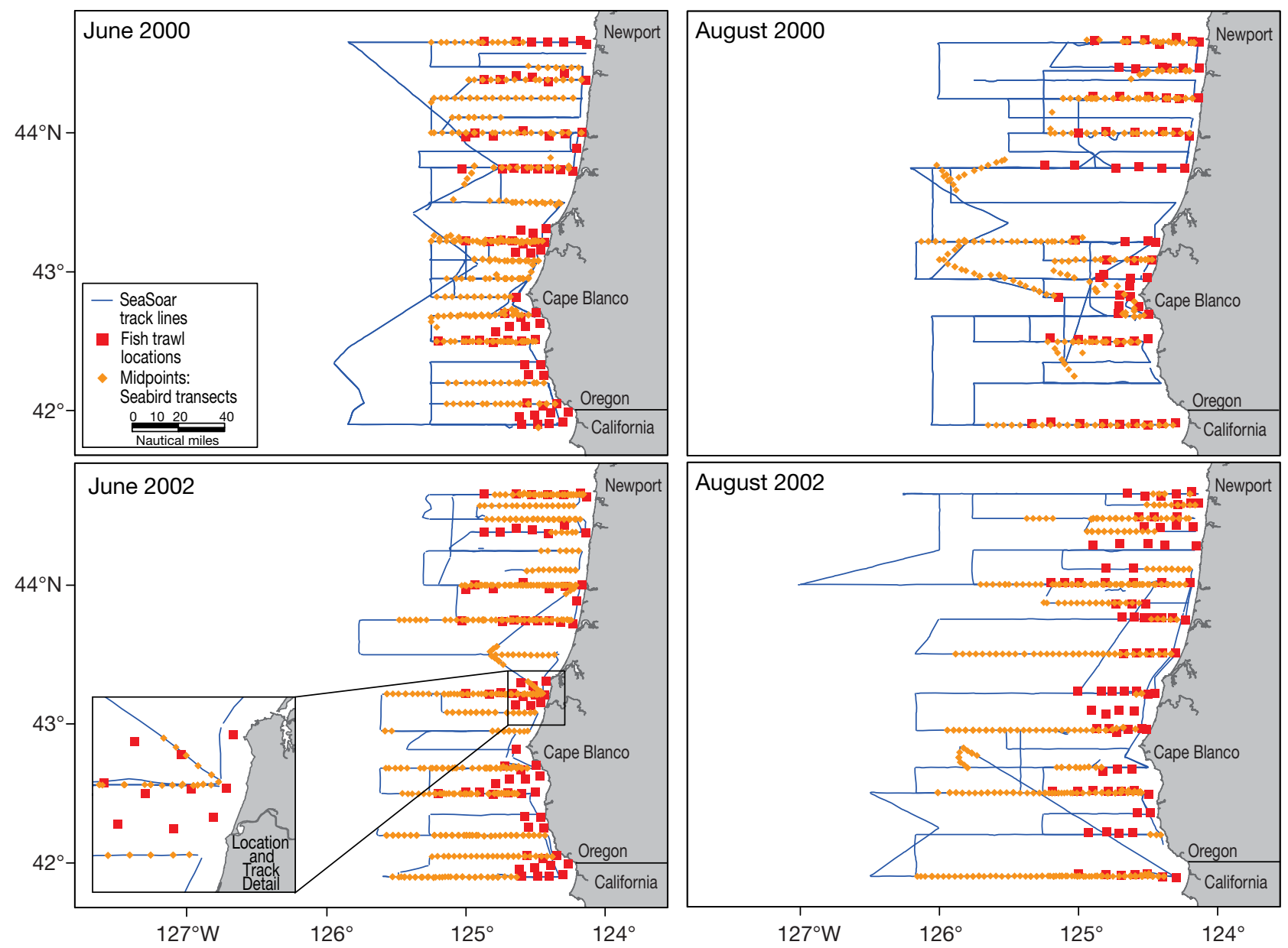

Fig. 1. Study area showing, for each of the 4 cruise periods, the SeaSoar track (blue lines) overlaid by positions of fish trawls (red squares), along with the start position of each of the individual segments of the seabird survey (orange diamonds) 
our between-track spacing and 7 times the size of the bins into which we combined our data (see next section).

During 2002, seabird surveys were conducted from the vessels that were towing the arrays, RV 'Thomas B. Thompson' and RV 'Roger Revelle', during the June and August cruises, respectively. These vessels were ideal for continuous seabird surveys and, thus, none of the issues described in the previous paragraph applied in 2002. The MOCNESS and trawl sampling proceeded on other vessels as in 2000.

Data collection. Bird surveys and binning of data: Seabird surveys were conducted continuously during daylight, using a $300 \mathrm{~m}$ wide transect strip. Within that strip, birds that occurred within the $90^{\circ}$ quadrant off the ship's bow that offered the best observation conditions were counted. Two observers were on watch during all survey periods (Spear et al. 2004). The total surface of ocean scanned for birds was as follows: 802.1 and $704.2 \mathrm{~km}^{2}$ (98 and $83 \mathrm{~h}$ ) in the 2 cruises in 2000 , and 937.4 and $742.5 \mathrm{~km}^{2}$ (126 and $\left.149 \mathrm{~h}\right)$ in the 2 cruises in 2002. For each bird sighted within the survey strip, we noted behavior: resting on the water, feeding or circling over a potential food source, attracted to the ship, or flying in a steady direction. For the latter behavior, we noted flight direction to the nearest $10^{\circ}$. Among attracted individuals, we recorded only those that approached the ship from the direction included within the $90^{\circ}$ quadrant being sampled. Thus, birds that were attracted but that appeared from behind or from the opposite side of the quadrant were not counted (Spear et al. 2004).

A new transect was started every 15 min contiguous with the previous transect. These survey segments were used to bin the environmental data derived from the SeaSoar, acoustics, and trawls (see next section) as well as the bird density estimates and thus represented the sample unit. Segments (bins) averaged $\sim 4.3 \mathrm{~km}$ (range: 3 to $5 \mathrm{~km}$ ) in length depending on bird survey vessel speed. Only those segments including SeaSoar and acoustic effort could be used to model bird density. Moreover, we only used segments that were within the area bounded by where fish trawls were made, i.e. the fish trawls defined the larger boundaries of the study area used for analysis. Thus, transect or survey segment was the sample unit and 340 transects in 2000 and 471 in 2002 met these criteria and were used in the analysis (Table 1).

Hydrographic and bioacoustic data: Most oceanographic data were collected using a towed, undulating vehicle known as 'SeaSoar' (Pollard 1986). The vehicle was cycled rapidly from the surface to depth while being towed at $3.5 \mathrm{~m} \mathrm{~s}^{-1}$ ( 7 knots). The vehicle was equipped with a Sea-Bird 9/11 plus CTD instrument with dual T/C sensors mounted to point forward through a hole in the SeaSoar nose. A WET Labs Flashpak fluorometer, using $490 \mathrm{~nm}$ (30 nm band pass) excitation and $685 \mathrm{~nm}$ detection wavelengths, was used to estimate chlorophyll concentration $\left(\mathrm{mg} \mathrm{m}^{-3}\right)$. The fluorescence signal was calibrated with discrete samples, collected by the MOCNESS vessel, measured using HPLC. Most of the temperature and salinity data were collected by cycling SeaSoar on a bare hydrographic cable from 0 to $120 \mathrm{~m}$ and back to the surface every $4 \mathrm{~min}$. The result was hydrographic data with high spatial resolution $(1.25 \mathrm{~km}$ between along-track surface points, $500 \mathrm{~m}$ between profiles at mid-depth) obtained rapidly (cross-margin sections in 2 to $10 \mathrm{~h}$ and large-area maps in 2 to $6 \mathrm{~d}$ ) so that a detailed 'snapshot' of the system could be obtained. Over the continental shelf, SeaSoar was cycled from 0 to 55 to $0 \mathrm{~m}$ every $1.5 \mathrm{~min}$, a pattern that resulted in along-track profile spacing of $300 \mathrm{~m}$ between shallow profiling surface points $\left(90 \mathrm{~s} \times 3.5 \mathrm{~m} \mathrm{~s}^{-1}\right)$. To sample to greater depths over the continental slope, SeaSoar was also towed using a faired cable cycling from 0 to 300 to $0 \mathrm{~m}$ every $8 \mathrm{~min}$. Concurrently, vertical profiles of horizontal velocity were measured using a hull-mounted acoustic Doppler current profiler (ADCP); further details of this data set can be found in Barth et al. (2005).

Using time-varying lags and an optimized thermal mass correction, the $24 \mathrm{~Hz}$ temperature and conductivity data were corrected and used to calculate $24 \mathrm{~Hz}$ salinity, and then averaged to yield $1 \mathrm{~Hz}$ values (Barth

Table 1. Flux-adjusted total counts across all transects in each year ( $\mathrm{n}=340$ in 2000, 471 in 2002), and the number (\%) of transects in which birds were present for the 6 bird species included in analyses

\begin{tabular}{|c|c|c|c|c|}
\hline \multirow[t]{2}{*}{ Species } & \multicolumn{2}{|c|}{2000} & \multicolumn{2}{|r|}{-2002} \\
\hline & Ind. & No. of transects (\%) & Ind. & No. of transects (\%) \\
\hline Black-footed albatross Phoebastria nigripes & 201 & $63(19)$ & 579 & $96(20)$ \\
\hline Pink-footed shearwater Puffinus creatopus & 269 & $66(19)$ & 851 & $68(14)$ \\
\hline Sooty shearwater Puffinus griseus & 6930 & $244(72)$ & 606 & $55(12)$ \\
\hline Fork-tailed storm-petrel Oceanodroma furcata & 368 & $46(14)$ & 4251 & $60(13)$ \\
\hline Common murre Uria aalge & 1819 & $102(30)$ & 1274 & $130(28)$ \\
\hline Cassin's auklet Ptychoramphus aleuticus & 443 & $52(15)$ & 4678 & $51(11)$ \\
\hline
\end{tabular}


et al. 2000). The final $1 \mathrm{~Hz}$ data files contain unfiltered GPS latitude and longitude, pressure, temperature, salinity, density anomaly (sigma t) computed using the 1980 equation of state, chlorophyll concentration $\left(\mathrm{mg} \mathrm{m}^{-3}\right)$, and date and time of day. The $1 \mathrm{~Hz}$ SeaSoar CTD data were averaged into 2 dbar vertical bins corresponding to the bird effort. These data were used to compute environmental parameters including thermocline depth and strength, and chlorophyll maximum concentration. These data were then integrated with the along-track data for bird densities.

Acoustic volume backscattering data were collected with a Hydroacoustics Technology (HTI) multi-frequency $(38,120,200$, and $420 \mathrm{kHz})$ model 244 towed bioacoustics instrument. The downward-looking transducers were mounted in a towed dead-weight vehicle deployed on a short fixed cable off the side of the ship. At typical tow speeds $\left(3.5 \mathrm{~m} \mathrm{~s}^{-1}\right)$, the transducers were at a depth of about $4 \mathrm{~m}$. We configured the instrument to collect volume backscattering (i.e. echo integration) data using a raw ping rate of 4 pings $\mathrm{s}^{-1}$, or 1 ping $\mathrm{s}^{-1}$ for each frequency. The raw data were collected into $12 \mathrm{~s}$ ensemble averages.

Nekton trawls: Nekton samples were conducted from chartered fishing vessels, the FV 'Sea Eagle' in 2000 and the FV 'Frosti' in 2002. At each trawl station, nekton collections were made with a Nordic 264 rope trawl (Nor'Eastern Trawl Systems) towed in the surface layer for $30 \mathrm{~min}$ at a speed of $6 \mathrm{~km} \mathrm{~h}^{-1}$ (see Brodeur et al. 2004 for additional sampling details). Most collections took place during daytime, but occasionally tows were made during twilight or nighttime (June 2000, $\mathrm{n}=84$ tows; August 2000, n = 75 tows; June 2002, $\mathrm{n}=90$ tows; August 2002, $\mathrm{n}=94$ tows). Analyses included here were limited to collections made during daylight hours, since this is the time period during which birds forage and day and night community structures may differ. Nekton abundance was then standardized for differences in effort between tows based on the volume of water filtered per trawl (see Reese \& Brodeur 2006).

Data analysis. Bird density: The comparatively rapid movement of flying birds is one of the most serious forms of bias encountered during seabird surveys at sea (Spear et al. 1992, 2004). Random directional movement (as opposed to non-random directional movement, which occurs when birds are attracted or repelled from the survey vessel) typically results in density over- estimation because most species fly faster than survey vessels, thus increasing encounter rates; densities of birds that fly slower or at a similar speed as the vessel (e.g. storm-petrels Oceanodroma spp.), or are flying in the same direction, are usually underestimated (Spear et al. 1992). Therefore, raw counts were adjusted for this survey effect following Spear et al. (1992) using species-specific flight speeds from Spear \& Ainley (1997). Flux-adjusted counts were converted to density by dividing the corrected count by the area surveyed in each cruise segment. Corrected densities (birds $\mathrm{km}^{-2}$ ) were calculated for each species observed on each cruise segment.

Environmental covariates: Data recorded at the start of each bird transect (cruise segment or bin) included the following: position, course, ocean depth, distance to nearest point on the mainland, wind speed and direction (nearest $10^{\circ}$ ), and speed and course of the vessel. Also for each transect, averaged for the bin sizes described in 'Bird surveys and binning of data', SeaSoar data (described in 'Hydrographic and bioacoustic data') were used to determine sea surface temperature and salinity (SST and SSS), chlorophyll a concentration by depth (from which the chlorophyll maximum and its depth was determined), as well as thermocline and pycnocline depths and their gradients (Table 2). These latter covariates were each identified as the shallowest inflection point determined from

Table 2. Covariates used to model presence-absence and bird density (fluxcorrected counts of ind $\mathrm{km}^{-2}$ ). ColDist was applicable only for Cassin's auklet, common murre and fork-tailed storm-petrel. Covariate bin size was the same as for individual seabird transect segments (average $4.3 \mathrm{~km}$ )

\begin{tabular}{|c|c|}
\hline Covariate & Description \\
\hline Cruise & June vs. August \\
\hline DPTH & Ocean depth (m) \\
\hline SST & Sea surface temperature $\left({ }^{\circ} \mathrm{C}\right)$ \\
\hline SSS & Sea surface salinity (ppt) \\
\hline ColDist & Sum $\left(\right.$ Colony Size $\times$ Dist $\left.^{-2}\right)$ for all colonies \\
\hline CHLMX & Chlorophyll maximum (V) \\
\hline MAX_dp & Depth of chlorophyll maximum (dbar) \\
\hline MLD & Thermal mixed-layer depth (dbar) \\
\hline ThSlp & Thermocline slope $\left(\Delta^{\circ} \mathrm{C}\right.$ per $\left.20 \mathrm{~m}\right)$ \\
\hline Pyc_dpt & Pycnocline depth (dbar) \\
\hline ZD_sm & Density (ind. $\mathrm{m}^{-3}$ ) small zooplankton, 3-4 mm \\
\hline ZD_med & Density (ind. $\mathrm{m}^{-3}$ ) medium zooplankton, $5-10 \mathrm{~mm}$ \\
\hline ZD_lg & Density (ind. $\mathrm{m}^{-3}$ ) large zooplankton, $11-24 \mathrm{~mm}$ \\
\hline Fish & Density (ind. $\mathrm{m}^{-3}$ ) small fish $>24 \mathrm{~mm}$ \\
\hline DistB & Distance to Feature B $(\mathrm{km})$ \\
\hline DistB $^{2}$ & Absolute value of distance to Feature $\mathrm{B}(\mathrm{km})$ \\
\hline GroupA & Ind. $\mathrm{km}^{-3}$ of adult and subadult salmon \\
\hline GroupB & $\begin{array}{l}\text { Ind. } \mathrm{km}^{-3} \text { of small mid-water fish: clupeids, juvenile } \\
\text { salmon }\end{array}$ \\
\hline GroupC & Ind. $\mathrm{km}^{-3}$ of market squid \\
\hline GroupD & Ind. $\mathrm{km}^{-3}$ of juvenile demersal fish \\
\hline GroupE & Ind. $\mathrm{km}^{-3}$ of adult sardines, saury \\
\hline
\end{tabular}


graphs plotting temperature or salinity as a function of depth. Exceptions occurred where there was no inflection point and in that case, given no indication of a mixed layer, thermocline depth was recorded as being at the ocean surface (i.e. $0 \mathrm{~m}$ depth). We measured thermo or pycnocline gradient as the temperature or salinity difference (nearest $0.1^{\circ} \mathrm{C}$ for temperature and $0.01 \%$ for salinity) from the bottom of the mixed layer (mixed-layer depth, MLD) to $20 \mathrm{~m}$ below the inflection.

In our initial analysis (Ainley et al. 2005), we used distance to various along- and cross-shelf features defined by location of (1) 11.5 to $12.0^{\circ} \mathrm{C}$ isotherm and as defined by dynamic height (see Reid \& Mantyla 1976; $\mathrm{J} \mathrm{kg}^{-1}\left[\mathrm{~m}^{2} \mathrm{~s}^{-2}\right]$ relative to 100 dbar, i.e. apparent pressure associated with a column of water, as affected by temperature and salinity); (2) the boundary where strong cross-shelf gradients in dynamic height relaxed, i.e. the outer edge of strong environmental gradients that marked the inshore edge of the upwelling jet; and (3) the jet's center and highest elevation. These 3 features were all highly correlated with each other in both years ( $r=0.60043$ to 0.77615 ), and with pycnocline depth in 2002 ( $r$ > 0.64023). Thus, we included only the second feature in the current analysis (Feature B in Ainley et al. 2005); feature values were increasingly positive as distances increased in an offshore direction and increasingly negative as distances increased in an inshore direction. To determine whether the upwelling feature itself was important (as opposed to the directional relationship), we developed an additional distance variable by squaring all the values (DistB ${ }^{2}$ ). Thus, small values represented distances closer to the feature and larger values represented distances farther from the feature, both offshore and inshore. In addition, distance from breeding colony was included in the model for locally breeding species, as these had colonies at discrete locations in the vicinity of the surveys.

Cruise (i.e. June vs. August) was also included as a covariate. This allowed us to control for potential changes in bird density associated with the time of season (breeding vs. migrating), an important consideration for some species (Ainley et al. 2005). Cruise also reflected potential seasonal changes in the fish fauna.

We explored the option of using humpback whale Megaptera novaeangliae abundance as a covariate, but for the time being could not deal with issues of their relative rarity compared to seabirds. In the 'Discussion', however, we will make some comments about their possible influence on the basis of comparisons with another study done in the study area at the time.

Seabird species spatial overlap: Having obtained results of statistical modeling to look at importance of environmental relationships, as an a posteriori exercise we explored the degree to which the 3 most abundant seabird species and the ones most likely to have very high diet overlap (similar body size, subsurface foraging) - sooty and pink-footed shearwaters, and common murre-co-occurred in the study area. We used the transect database described above to generate $2 \times$ 2 presence-absence matrices for all pairwise combinations of the 3 species for each cruise. Each transect was categorized as to whether it contained foraging activity by Species A only, Species B only, both Species A and Species B, or neither Species A nor Species B. Foraging activity was defined as 1 or more birds engaged in feeding behavior. The resultant matrix was analyzed using Cole's index (Cole 1949) to determine whether pairs of species were more or less likely to be found on the same transect as would be expected if their distributions were entirely independent of each other. Cole's index has been used in other studies of potentially competing species to determine whether they are attracted or repelled by each other's presence (e.g. Ainley \& Boekelheide 1990).

Indices of association are based on whether or not sampling units that could contain a particular species or behavior actually does contain that species or behavior. Results based on these indices are sensitive to the specification of the null category, i.e. the category in which nothing is observed (Gotelli 2000). For example, consider the case where there is 1 observation of Species A and Species B in the same sampling unit, and no other observation of either species anywhere else. If there were only 1 other sampling unit, and that unit contained neither species, there would be little evidence that the 2 species were positively associated. By chance alone, the 2 observations would be expected to occur in the same sampling unit about half the time. But if there were 1000 empty sampling units, then the occurrence of the only 2 observations in the same cell would strongly suggest that the 2 species were positively associated.

In this analysis, we assumed that foraging activity could potentially occur on any transect. However, the database undoubtedly contains many transects in which the absence of foraging behavior by either species results from the absence of prey along those transects, and these transects are not relevant to the question of whether or not Species A and Species B are significantly associated when foraging. These transects were included in the analysis since we lack an independent method for determining whether a transect contained actual foraging opportunities. Their inclusion inflates the estimated number of transects in the sample universe where foraging could occur, and correspondingly increases the likelihood of Type II error. Results of this analysis should therefore be interpreted as conservative in terms of identifying significant positive or negative associations between species. 
Micronekton and macronekton-acoustics: The acoustic volume backscattering data (Sv) at 4 frequencies $(38,120,200$, and $420 \mathrm{kHz})$ were used to estimate abundances within the ensonified volume. For zooplankton, we assumed a randomly oriented, fluid-filled bent-cylinder acoustic backscattering cross-section model in the form used by Greene et al. (1998) from the models of Stanton et al. (1994), and for fish we use the model of Love (1971). Using these models, for each frequency we assumed the total backscatter within the ensonified volume (as measured) was the sum of each backscattering cross-section of the size class times the abundance in that size class. The resulting set of equations was then solved for the abundances, using a non-negative least-squares algorithm (Greenlaw 1979). Here we solved for abundances in the 3 zooplankton

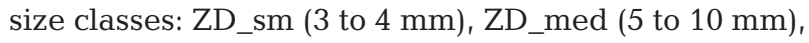
ZD_lg (11 to $24 \mathrm{~mm})$, plus the fish class (>24 mm; Table 2). These results were then averaged vertically (15 to $100 \mathrm{~m}$ ) and horizontally to match the seabird sampling bins. For more details and bioacoustic data access, see http://damp.coas.oregonstate.edu/globec/ nep/hti.

Good reviews of the extensive field of zooplankton bioacoustics can be found in Foote \& Stanton (2000).

Macronekton and fish trawls: Based on the known diet of the seabird species we modeled (Ainley \& Sanger 1979, Briggs \& Chu 1987, Ainley et al. 1996), we separated the fish found in trawls into 5 groups: (A) adult and subadult Chinook salmon Oncorhynchus tshawytscha and coho salmon O. kisutch; (B) small mid-water fishes, including juvenile salmon, northern anchovy Engraulis mordax, surf smelt Hypomesus pretiosus, and Pacific herring Clupea pallasi; (C) market squid Loligo opalescens; (D) juvenile demersal fish, such as rockfish Sebastes spp.; and (E) adult Pacific sardines Sardinops sagax and Pacific saury Cololabis saira (Table 2). Since seabird surveys and fish trawls were not fully synchronized, fish density for each segment of the seabird surveys (see next paragraph) was estimated using geostatistical modeling techniques based on values obtained from trawl results. This method of determining spatial distributions of fish species and various community characteristics has been previously used and described in detail by Reese \& Brodeur (2006). For each species we collected and calculated the abundance at specified sample locations. The values obtained at the sample stations were then used to interpolate predicted values at all locations. Based on the station data, empirical semivariograms were calculated for each fish group during each cruise. The semivariogram is a geostatistical procedure in which variables tend to be more similar in value the closer they are spatially. Two types of directional components can affect surface predictions: global trends and anisotropy (Johnston et al. 2001), both of which were examined for each fish group and incorporated into the analyses when present.

Expected values of fish density were estimated for each cruise by kriging. Kriging forms weights based on surrounding measured values in order to predict values at unmeasured locations such that the closest measured values have the most influence on the predicted value (Johnston et al. 2001). The weights of each measured value are derived from the modeled semivariogram that characterizes the spatial structure of the data. Therefore, the weighting factor depends on the semivariogram, the distance to the prediction location, and the spatial relationships among the measured values in the vicinity of the prediction location. The benefit of utilizing this technique was that in addition to producing predicted surfaces, it provided a measure of the error associated with the predicted values (Johnston et al. 2001). In the absence of spatial correlation, an alternative interpolation method was employed to obtain the required spatial coverage. We chose to use inverse distance weighting (IDW), which is similar to kriging in that it weights the surrounding measured values to derive a prediction for each location; however, the weightings are based only on the distance between the measured points and the prediction location and do not depend on spatial correlation in the data (Johnston et al. 2001).

Estimates of the abundance of each of these fish groups were made for each of the cruise segments (i.e. transects or bins) into which the data from bird surveys, SeaSoar, and acoustics had been binned. To prevent the use of extrapolated values of fish densities with extrapolated values of other covariates, all data were pruned such that only transects including data with non-extrapolated predictions of fish densities within the associated bins were used for further analyses.

Statistical modeling. Although 34 avian species were observed during surveys in 2000 and 2002, many of these species were observed on very few transects, therefore precluding their use in this analysis. We chose to statistically investigate the 6 most abundant avian species (Table 1), but a high proportion of 'zeros' characterized these data as well (28 to $89 \%$ of total transects). To address this problem, we chose to analyze these data in 2 stages, similar theoretically to the 2-step modeling approach advocated by Dobbie \& Welsh (2001) and Cunningham \& Lindenmayer (2005). We analyzed the presence-absence data (birds present vs. not present on transect) using a logistic regression model (Proc GENMOD; SAS Institute), and we modeled density (birds $\mathrm{km}^{-2}$ ) using general linear modeling (Proc MIXED; SAS Institute ) for only those survey segments on which birds were sighted. Another benefit of this 2-step approach is that it allowed modeling of 
both these aspects of the data (presence-absence vs. density) separately and we could therefore gain insight into whether they are being influenced by biotic and abiotic factors in different ways (Fletcher et al. 2005). Moreover, the presence-absence picture reveals relationships at the mesoscale or above, while the density (per transect) picture allows a smaller-scale investigation of predators, competitors, and their prey. It is now well known that seabirds forage at nested scales, first finding a region of higher food availability and then once in that region, increasing the search effort to locate prey patches (e.g. Logerwell et al. 1998, Fauchald et al. 2000, Pinaud \& Weimerskirch 2005, 2007, Weimerskirch 2007).

Survey transects within a particular day tended to occur sequentially or within $\leq 2 \mathrm{~h}$ between surveys. Thus, for our logistic regressions we used a first-order autoregressive structure on variances with year-day as a blocking effect, because we expected survey segments (transects) within days to be more highly correlated than survey segments between days (Ainley et al. 2005). Before modeling density, we used restricted maximum likelihood estimation to examine several variance structures to account for any autocorrelation or lack of independence between survey segments in each reduced data set. In addition to the first-order autoregressive structure, we also investigated independent (within-subject error correlation is zero) and compound symmetric structures (Littell et al. 2002). In most cases the best variance structure was a first-order autoregressive, but for Cassin's auklet in 2002 and fork-tailed storm-petrel in 2002, compound symmetric performed better, and for fork-tailed storm-petrel in 2000, the independent variance was the best structure. For each species, the best variance structure was used in further general linear modeling.

We applied this 2-step analytical approach to 2 data sets generated for each of the 6 numerically dominant species encountered in the study area over both years, which included black-footed albatross, pink-footed shearwater, sooty shearwater, fork-tailed storm-petrel, common murre, and Cassin's auklet (see Ainley et al. 2005 for complete list of species encountered; Table 1 for scientific names). A presence-absence data set was generated including all transects surveyed, which also included a complete set of biotic and abiotic covariates ( $\mathrm{n}=340$ in 2000, 471 in 2002). A second data set was generated to investigate the effects of biotic and abiotic factors on density when birds were present, so for each species this data set only included transects on which birds were observed (n varied depending on species; Table 1).

We used an information-theoretic approach (Burnham \& Anderson 2002) to choose the best models for each species, including an initial stage where we deter- mined the best variance structure for the bird density data (see paragraph above). This approach requires the development of an a priori model set and the use of a model selection criterion to find the best approximating model given the data and model set. We developed $a$ priori single-factor model sets that investigated the effect of all the covariates of interest (Table 2) on presence-absence and bird density. For the linear modeling of seabird density, we used Akaike's information criterion corrected for small sample sizes $\left(\mathrm{AIC}_{\mathrm{c}}\right)$, with delta $\mathrm{AIC}_{\mathrm{C}}\left(\Delta \mathrm{AIC}_{\mathrm{C}}\right)$ and $\mathrm{AIC}_{\mathrm{c}}$ weights to aid in model selection (see Burnham \& Anderson 2002). Models with the lowest $\mathrm{AIC}_{\mathrm{C}}$ were generally considered best, but the degree to which $95 \%$ CIs for covariate coefficients overlapped zero was also used to evaluate competing models $\left(\Delta \mathrm{AIC}_{\mathrm{c}}<2\right)$ and specific explanatory variables (Cooch \& White 2006). Multi-factor models were developed a posteriori if they seemed warranted based on initial model selection results. We did not include highly correlated covariates $(\mathrm{r}>0.60$, Spearman rank correlations) in the same model and bird density data were log-transformed.

We used the same general approach for modeling presence-absence data, but used the generalized estimating equations (GEE) approach to handle the correlated response data associated with the logistic regression modeling of seabird presence. Because GEE is not likelihood-based, AIC model selection criteria cannot be used. Instead we used the quasi-likelihood under independence criteria (QIC) developed by Pan (2001) to find a best approximating model given the data and the model set. We generated delta QIC ( $\triangle$ QIC) and QIC weights following procedures outlined for $\mathrm{AIC}_{\mathrm{C}}$ by Burnham \& Anderson (2002) to aid in model selection. We evaluated these model selection criteria similarly to $\mathrm{AIC}_{\mathrm{C}}$ selection outlined in the previous paragraph.

\section{RESULTS}

The oceanographic climate and the abundance of various zooplankton and fish differed markedly between 2000 and 2002 as evidenced by the lack of overlap in CIs between years for many covariates (Table 3). Potential seabird prey were much more abundant during 2002 as evidenced in the higher values for all zooplankton size groups and most fish groups.

\section{General relationships among avian predators}

The 6 species included in our analysis are the most abundant representatives in the NCC of (1) a large, surface-feeding generalist (black-footed albatross); 
Table 3. Mean, SE, and 95\% CI for all habitat features and prey abundance covariates associated with transects used to model bird presence-absence in each year (340 in 2000, 471 in 2002). See covariate descriptions in Table 2

\begin{tabular}{|c|c|c|c|c|c|c|}
\hline \multirow{2}{*}{ Covariate } & \multicolumn{3}{|c|}{2000} & \multicolumn{3}{|c|}{2002} \\
\hline & Mean & SE & $95 \% \mathrm{CI}$ & Mean & SE & $95 \% \mathrm{CI}$ \\
\hline DPTH & 391.92 & 32.85 & 327.30 to 456.54 & 384.78 & 25.91 & 333.87 to 435.70 \\
\hline $\mathrm{SST}^{\mathrm{a}}$ & 12.61 & 0.08 & 12.46 to 12.77 & 11.55 & 0.08 & 11.40 to 11.69 \\
\hline $\mathrm{SSS}^{\mathrm{a}}$ & 32.23 & 0.04 & 32.15 to 32.31 & 31.82 & 0.10 & 31.62 to 32.02 \\
\hline ColDist & 1.10 & 0.05 & 1.00 to 1.19 & 1.02 & 0.03 & 0.96 to 1.07 \\
\hline CHLMX $^{\mathrm{a}}$ & 4.30 & 0.26 & 3.79 to 4.81 & 0.83 & 0.03 & 0.78 to 0.88 \\
\hline MAX_dp & 14.80 & 0.64 & 13.53 to 16.06 & 15.20 & 0.68 & 13.87 to 16.53 \\
\hline MLD & 6.66 & 0.28 & 6.11 to 7.21 & 5.88 & 0.21 & 5.48 to 6.29 \\
\hline ThSlp & 2.75 & 0.07 & 2.62 to 2.88 & 2.60 & 0.06 & 2.48 to 2.73 \\
\hline Pyc_dpt ${ }^{a}$ & 8.87 & 0.44 & 8.00 to 9.74 & 46.46 & 1.18 & 44.14 to 48.78 \\
\hline DistB $^{a}$ & 1.94 & 1.04 & -0.11 to 3.99 & -6.84 & 0.82 & -8.45 to -5.23 \\
\hline ZD_sm ${ }^{\mathrm{a}}$ & 40.13 & 3.78 & 32.70 to 47.56 & 180.85 & 26.71 & 128.37 to 233.32 \\
\hline ZD_med ${ }^{\mathrm{a}}$ & 7.78 & 0.68 & 6.45 to 9.10 & 69.62 & 11.17 & 47.67 to 91.56 \\
\hline ZD_lg $\lg ^{\mathrm{a}}$ & 3.25 & 0.26 & 2.74 to 3.76 & 7.83 & 0.63 & 6.60 to 9.06 \\
\hline Fish $^{\mathrm{a}}$ & 0.0009 & 0.0001 & 0.0008 to 0.0010 & 0.004 & 0.0005 & 0.003 to 0.005 \\
\hline GroupA $^{a}$ & 0.58 & 0.08 & 0.43 to 0.73 & 0.92 & 0.06 & 0.82 to 1.03 \\
\hline GroupB $^{a}$ & 18.90 & 2.27 & 14.44 to 23.37 & 42.70 & 2.82 & 37.17 to 48.24 \\
\hline GroupC $^{\mathrm{a}}$ & 0.28 & 0.004 & 0.20 to 0.36 & 26.99 & 2.04 & 22.99 to 31.0 \\
\hline GroupD ${ }^{a}$ & 16.77 & 2.33 & 12.18 to 21.36 & 4.49 & 0.26 & 3.98 to 5.01 \\
\hline Group $^{a}$ & 1.49 & 0.24 & 1.02 to 1.96 & 6.51 & 0.64 & 5.25 to 7.77 \\
\hline
\end{tabular}

(2) a small, surface-feeding planktivore (fork-tailed storm-petrel); (3) 2 mid-sized, shallow diving (to $15 \mathrm{~m}$ ) piscivores (sooty shearwater, pink-footed shearwater); (4) a mid-sized, deep-diving (to $100 \mathrm{~m}$ ) piscivore (common murre); and (5) a small, mid-depth diving (20 to $80 \mathrm{~m}$ ) planktivore (Cassin's auklet).

\section{Black-footed albatross}

In 2000, the presence-absence of this surface-feeding generalist was affected by a variety of potential prey classes, but most strongly by the presence of potential competitors, adult and subadult salmon (Table 4, Fig. 2). When salmon densities increased, albatross presence decreased, an important relationship in all 3 of the top models. However, competitive models also suggested that the probability of albatross presence in 2000 decreased with increased density of medium zooplankton (ZD_med) and increased with densities, in turn, of the zooplanktons' predators and albatross' prey: small mid-water fish, including juvenile salmon (GroupB) and juvenile demersal fish (GroupD) (Table 4). The negative relationship of albatross with salmon competitors is consistent with the positive relationship seen with salmon prey.

In contrast, in 2002 physical oceanographic features had the strongest effect on albatross presenceabsence, with increased presence closest to Feature B $\left(\right.$ DistB $\left.^{2}\right)$ and associated with lower SSS. A competitive model also supported the positive effect of juvenile demersal fish density (prey), as in 2000, in addition to nearness to Feature B (Table 4).

Similar to presence, higher blackfooted albatross densities in 2000 were most strongly associated with decreased density of medium zooplankton (ZD_med) and increased densities of albatross prey, i.e. small mid-water fish (GroupB) and juvenile demersal fish (GroupD); whereas densities in 2002 were affected by physical oceanographic features (Table 5). In that year, albatross densities were lower at greater pycnocline depths (Pyc_dpt) and higher inshore of Feature B (DistB). There was some support for a relationship with chlorophyll maximum (CHLMX) as it occurred in our top model as well as another that was competitive, but the $95 \%$ confidence limits on the beta for this effect included zero and was thus a weaker effect. Finally, there was some support for a positive relationship with high density of adult and subadult salmon, which, while competitors for food (Table 5), could well drive prey closer to the surface, making them more available to the non-diving albatross.

\section{Pink-footed shearwater}

Presence-absence of this shallow-diving seabird was strongly affected by cruise in 2000, with a higher presence during the second cruise. This would be consistent with the shearwaters' migration into the study area from nesting areas in the southern Peru Current after their austral summer (boreal winter) breeding. In addition, our best model included a strong negative effect of depth and an interaction between the density of adult and subadult salmon and cruise (Table 4 ; Fig. 3). Thus, the occurrence of pink-footed shearwaters was highest at shallower ocean depths (DPTH), i.e. the continental slope, and positively influenced by the density of adult and subadult salmon (GroupA), especially later in the season (Cruise 2), but negatively influenced by the density of salmon early in the season (Cruise 1). Consistent with these birds being associated with predatory fish and marine mammals (D. G. Ainley pers. obs.), the salmon would likely drive prey nearer to the surface. Interestingly, cruise had only a weak effect on pink-footed shearwater presence during 2002, but presence was increased at shallower ocean depths and where SSS was decreased (Table 4). Shear- 
water presence was also less likely where the pycnocline was deeper (Table 4). In other words, these birds were associated with waters overlying the continental slope and not close to the most intense upwelling.

In 2000, pink-footed shearwater density was highest at the upper levels of chlorophyll concentration and while none of the other single-factor models investigated were within $2 \mathrm{AIC}_{\mathrm{C}}$, the $95 \%$ CIs on the distance from Feature $B$, the density of adult and subadult salmon, the depth of the maximum chlorophyll, and the depth of the thermal mixing layer all excluded zero, indicating some support for the effect of these covariates on shearwater density (Table 5). In contrast, higher densities of pink-footed shearwater in 2002 were associated with higher densities of adult and subadult salmon only, with no other covariates receiving any support (Table 5).

\section{Sooty shearwater}

These medium depth-diving birds, another seasonal visitor to the NCC, were the most abundant species (Ainley et al. 2005). They arrive from breeding colonies in the southwest Pacific in April and May, earlier than pink-footed shearwater, and depart by August. The importance of cruise, a surrogate for time of year, in explaining their occurrence patterns and density in both years was consistent with this behavior; in contrast to pink-footed shearwaters, another southern hemisphere breeder, these birds were far more abundant earlier in the summer than later (Table 4, Fig. 4). Sooty shearwaters fly much more rapidly than pink-footed shearwaters (Spear \& Ainley 1997) and on that fact alone would be expected to arrive earlier; moreover the pink-foot initially flies over the very productive Peru Current, perhaps slowing its travel (see Ballance et al. 1997). These differences are consistent with the importance of year-day in the analysis by Ainley et al. (2005), and with higher shearwater densities noted earlier in the season during the present study. In 2000, the strongest support was for a
Table 4. Ranking of top 5 models relating environmental and biological covariates to the presence-absence of abundant seabird species during June and August 2000 and 2002, using quasi-likelihood under the independence criterion (QIC). The number of parameters $(k), \Delta$ QIC, and QIC weights (QIC wt) are given for all models. Sign of the slope coefficients $(\beta)$ are included, with positive $(+)$ and negative (-) denoting those with $95 \%$ CIs that do not include zero; otherwise, sign denoted as zero. Slope signs listed in same order as model coefficients. Intercept-only model included for comparison. See covariate descriptions in Table 2

\begin{tabular}{|c|c|c|c|c|}
\hline Model & $k$ & $\Delta \mathrm{QIC}^{\mathrm{a}}$ & QIC wt & $\beta$ \\
\hline \multicolumn{5}{|l|}{ Black-footed albatross, 2000} \\
\hline GroupA, ZD_med & 3 & 0.00 & 0.36 &,-- \\
\hline GroupD, GroupA & 3 & 0.67 & 0.25 &,+- \\
\hline GroupB, GroupA & 3 & 1.08 & 0.21 &,+- \\
\hline GroupD, ZD_med & 3 & 2.79 & 0.09 &,+- \\
\hline GroupB, ZD_med & 3 & 3.68 & 0.06 &,+- \\
\hline Intercept-only & 1 & 16.97 & 0.00 & \\
\hline \multicolumn{5}{|l|}{ Black-footed albatross, 2002} \\
\hline DistB $^{2}, \mathrm{SSS}$ & 3 & 0.00 & 0.51 &,-- \\
\hline DistB $^{2}$, GroupD & 3 & 1.07 & 0.30 &,-+ \\
\hline DistB $^{2}$, GroupC & 3 & 2.99 & 0.11 &,-- \\
\hline DistB $^{2}$, CHLMX & 3 & 5.31 & 0.04 &,- 0 \\
\hline $\operatorname{DistB}^{2}$ & 2 & 6.09 & 0.02 & - \\
\hline Intercept-only & 1 & 26.41 & 0.00 & \\
\hline \multicolumn{5}{|l|}{ Pink-footed shearwater, 2000} \\
\hline \multicolumn{5}{|l|}{ Cruise $^{\mathrm{b}}$, GroupA, DPTH, } \\
\hline Cruise $\times$ GroupA & 7 & 0.00 & 0.73 &,,,++-- \\
\hline Cruise, GroupA, Cruise $\times$ GroupA & 6 & 4.37 & 0.08 &,,++- \\
\hline Cruise, GroupA, GroupE, DPTH & 6 & 4.55 & 0.08 & $+, 0,0,-$ \\
\hline Cruise, GroupE, DPTH & 5 & 5.82 & 0.04 &,,++- \\
\hline Cruise, GroupA, DPTH & 5 & 6.58 & 0.03 &,,++- \\
\hline Intercept-only & 1 & 58.22 & 0.00 & \\
\hline \multicolumn{5}{|l|}{ Pink-footed shearwater, 2002} \\
\hline SSS, DPTH & 3 & 0.00 & 0.43 &,-- \\
\hline Pyc_dpt & 2 & 1.88 & 0.17 & - \\
\hline SSS & 2 & 3.31 & 0.08 & 0 \\
\hline Pyc_dpt, DPTH & 3 & 3.87 & 0.06 & 0,0 \\
\hline Cruise, SSS & 4 & 3.95 & 0.06 & 0,0 \\
\hline Intercept-only & 1 & 7.88 & 0.01 & \\
\hline \multicolumn{5}{|l|}{ Sooty shearwater, 2000} \\
\hline DPTH, GroupB, Cruise & 5 & 0.00 & 0.40 & $-, 0,0$ \\
\hline DPTH, GroupD, Cruise & 5 & 0.01 & 0.40 & $-, 0,0$ \\
\hline DPTH, GroupD & 3 & 2.96 & 0.09 &,- 0 \\
\hline DPTH, GroupB & 3 & 3.72 & 0.06 &,- 0 \\
\hline DPTH, Cruise ${ }^{c}$ & 3 & 4.59 & 0.04 &,-- \\
\hline Intercept-only & 1 & 44.77 & 0.00 & \\
\hline \multicolumn{5}{|l|}{ Sooty shearwater, 2002} \\
\hline Cruise $^{c}$, DPTH, CHLMX & 5 & 0.00 & 0.56 &,,--- \\
\hline Cruise, DPTH, CHLMX, GroupE & 6 & 0.48 & 0.44 &,,,--- 0 \\
\hline Cruise, DPTH, GroupE & 5 & 19.38 & 0.00 &,,-- 0 \\
\hline Cruise, DPTH & 4 & 20.79 & 0.00 &,-- \\
\hline Cruise, CHLMX & 4 & 23.05 & 0.00 &,-- \\
\hline Intercept-only & 1 & 54.25 & 0.00 & \\
\hline \multicolumn{5}{|l|}{ Fork-tailed storm-petrel, 2000} \\
\hline SSS, GroupB & 3 & 0.00 & 0.56 &,-+ \\
\hline SSS & 2 & 1.27 & 0.30 & - \\
\hline GroupB & 2 & 4.88 & 0.05 & + \\
\hline GroupD & 2 & 5.59 & 0.03 & + \\
\hline SST & 2 & 5.89 & 0.03 & + \\
\hline Intercept-only & 1 & 14.98 & 0.00 & \\
\hline Model & $k$ & $\Delta \mathrm{QIC}^{\mathrm{a}}$ & QIC wt & $\beta$ \\
\hline
\end{tabular}


Table 4 (continued)

\begin{tabular}{|c|c|c|c|c|}
\hline Model & $k$ & $\Delta \mathrm{QIC}^{\mathrm{a}}$ & QIC wt & $\beta$ \\
\hline \multicolumn{5}{|c|}{ Fork-tailed storm-petrel, 2002} \\
\hline GroupD & 2 & 0.00 & 0.94 & + \\
\hline GroupA & 2 & 8.02 & 0.01 & 0 \\
\hline SSS & 2 & 10.01 & 0.00 & - \\
\hline Pyc_dpt & 2 & 10.49 & 0.00 & 0 \\
\hline ThSlp & 2 & 10.79 & 0.00 & 0 \\
\hline Intercept-only & 1 & 0.00 & 0.00 & \\
\hline \multicolumn{5}{|l|}{ Common murre, 2000} \\
\hline DPTH, Pyc_dpt & 3 & 0.00 & 0.61 &,- 0 \\
\hline DPTH & 2 & 0.90 & 0.39 & - \\
\hline DistB, Pyc_dpt & 3 & 10.63 & 0.00 &,-- \\
\hline DistB & 2 & 17.72 & 0.00 & - \\
\hline SST & 2 & 38.07 & 0.00 & - \\
\hline Intercept-only & 1 & 97.14 & 0.00 & \\
\hline \multicolumn{5}{|l|}{ Common murre, 2002} \\
\hline Pyc_dpt, DPTH & 3 & 0.00 & 1.00 &,- 0 \\
\hline Pyc_dpt & 2 & 18.74 & 0.00 & - \\
\hline Pyc_dpt, DistB & 3 & 20.00 & 0.00 &,-- \\
\hline DistB & 2 & 43.95 & 0.00 & - \\
\hline DPTH & 2 & 59.25 & 0.00 & 0 \\
\hline Intercept-only & 1 & 131.15 & 0.00 & \\
\hline \multicolumn{5}{|l|}{ Cassin's auklet, 2000} \\
\hline Pyc_dpt, MAX_dp, ZD_lg & 4 & 0.00 & 0.50 & $0,-, 0$ \\
\hline MAX_dp, ZD_lg & 3 & 1.10 & 0.29 &,- 0 \\
\hline Pyc_dpt, ZD_lg & 3 & 2.65 & 0.13 & 0,0 \\
\hline Pyc_dpt, MAX_dp & 3 & 7.32 & 0.01 & 0,0 \\
\hline Pyc_dpt & 2 & 7.72 & 0.01 & 0 \\
\hline Intercept-only & 1 & 12.58 & 0.00 & \\
\hline \multicolumn{5}{|l|}{ Cassin's auklet, 2002} \\
\hline Pyc_dpt, ColDist & 3 & 0.00 & 1.00 &,-- \\
\hline ColDist & 2 & 9.61 & 0.01 & - \\
\hline Pyc_dpt & 2 & 11.04 & 0.00 & - \\
\hline GroupD & 2 & 18.64 & 0.00 & - \\
\hline DistB & 2 & 19.01 & 0.00 & - \\
\hline Intercept-only & 1 & 25.69 & 0.00 & \\
\hline \multicolumn{5}{|c|}{$\begin{array}{l}\text { 'Lowest QIC for: Cassin's auklet in } 2000 \text { was } 284.47 \text { and in } 2002 \text { was } 303.07 \text {; } \\
\text { black-footed albatross in } 2000 \text { was } 313.44 \text { and in } 2002 \text { was } 455.48 \text {; common } \\
\text { murre in } 2000 \text { was } 325.79 \text { and in } 2002 \text { was } 428.94 \text {; pink-footed shearwater } \\
\text { in } 2000 \text { was } 284.90 \text { and in } 2002 \text { was } 387.11 \text {; sooty shearwater in } 2000 \text { was } \\
367.36 \text { and in } 2002 \text { was } 600.90 \text {; fork-tailed storm-petrel in } 2000 \text { was } 260.00 \\
\text { and in } 2002 \text { was } 352.78 \\
\text { bBird density higher on } 2 \text { nd cruise compared to } 1 \text { st } \\
\text { cBird density higher on } 1 \text { st cruise compared to } 2 \text { nd }\end{array}$} \\
\hline
\end{tabular}

ocean depth (DPTH) and the maximum chlorophyll (CHLMX) (Table 4). Occurrence was higher on the first cruise, in association with shallower water, and at the lowest chlorophyll maximum values. There was also a weak association with the density of adult sardines and saury, but the $95 \%$ CIs of this beta overlapped zero, so this 2nd best model was largely competitive because of the cruise, ocean depth, and chlorophyll maximum covariates.

In 2000, sooty shearwater density, similarly associated with cruise as above, increased with the density of adult and subadult salmon (GroupA), i.e. possible symbionts, and there was some weak support for an interaction between cruise and salmon density as evidenced by our top model (Table 5). In 2002, in addition to cruise, sooty shearwater density increased at the shallower chlorophyll maximum depths and also at higher densities of forage fish, estimated from the acoustic data (FISH), i.e. potential prey. Ocean depth (DPTH) was correlated with depth of chlorophyll maximum (MAX_dp), so a model with DPTH instead of MAX_dp and FISH was highly competitive. The density of medium zooplankton (ZD_med) was also correlated with FISH density (potential predators of these zooplankton), and again these 2 covariates were equally supported in the top models (Table 5).

\section{Fork-tailed storm-petrel}

The presence of fork-tailed stormpetrels was most strongly related to

negative relationship between shearwater presence and water depth (DPTH), with a higher probability of sooty shearwater occurrence in shallower waters, thus inshore of pink-footed shearwaters (Table 4). Our best models for 2000 included relationships between presence of these birds and the density of small mid-water fish (GroupB) and juvenile demersal fish (GroupD) (Table 4). These fish categories were very highly correlated in 2000 , so both these covariates were equally supported in our best models. Although cruise was part of our best model, the $95 \%$ CIs for beta associated with the cruise effect included zero, so it was not as strong an effect in 2000, compared to 2002 (Table 4). In 2002, the presence of sooty shearwaters was strongly associated with physical correlates: cruise,
SSS and the density of small mid-water fish (GroupB), i.e. potential prey in 2000 (Table 4, Fig. 5), with higher probability of occurrence occurring in colder waters, where small mid-water fish densities were highest. In 2002, the occurrence of storm-petrels was positively related to the density of juvenile demersal fish (GroupD), another potential prey group (Table 4).

In 2000, fork-tailed storm-petrel density was most strongly related to the density of small mid-water fish (GroupB) with some weak support for the effect of ocean depth (DPTH) (Table 5). Density was higher in 2002 when pycnocline depth was shallower, and interestingly, there was again weak support for ocean depth as being important (Table 5). 

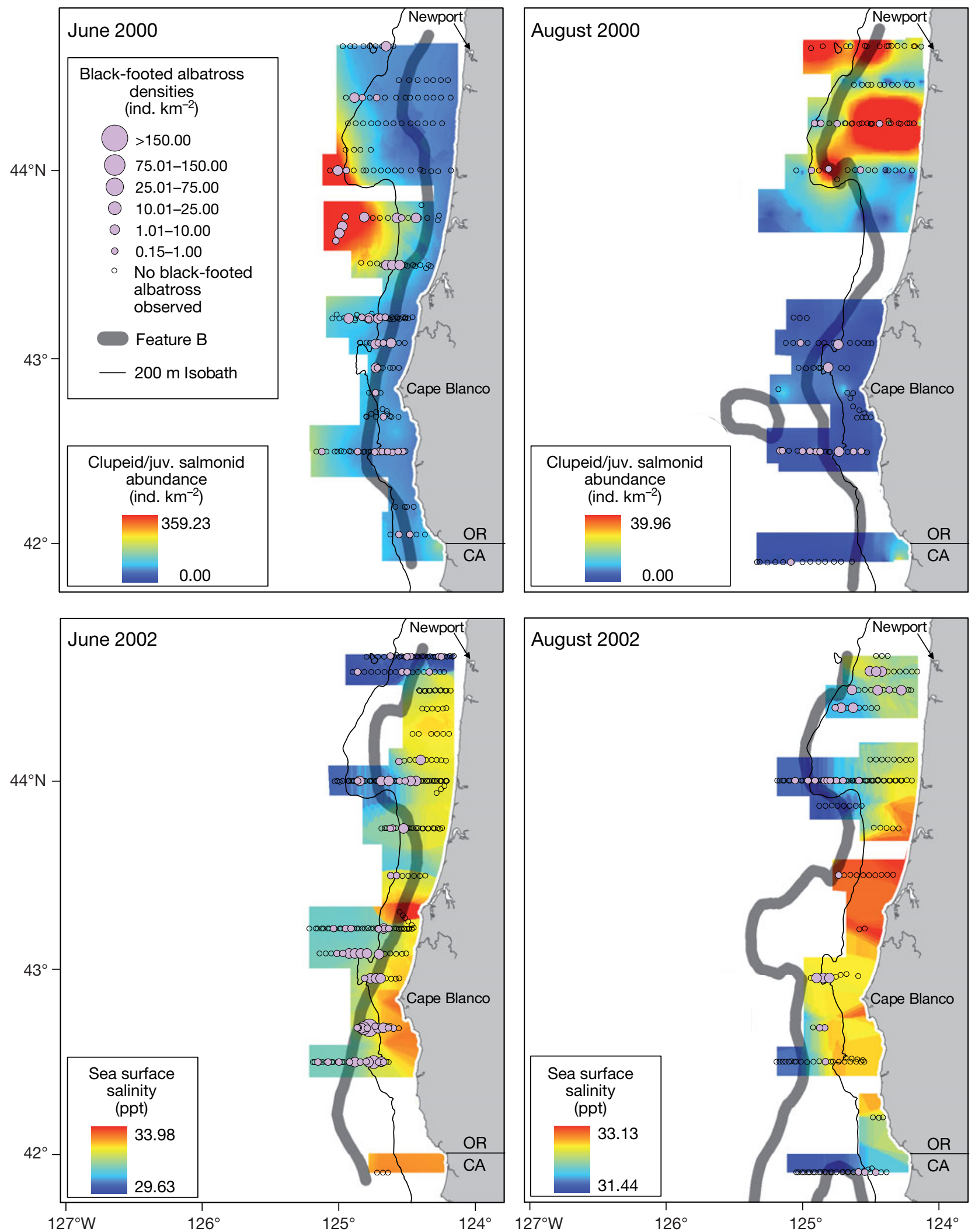

Fig. 2. Black-footed albatross occurrence patterns plotted as density in relation to covariate with strongest support based on model weights from both density and presence-absence analyses (Tables 2, 4 \& 5). In 2000, on transects where albatross occurred, density was related to density of small mid-water fish (GroupB). In 2002, albatross presence was related to sea surface salinity (SSS). Feature B (upwelling front) is shown by the shaded thick line, and the shelfbreak (200 $\mathrm{m}$ isobath) by the thin black line. OR: Oregon; CA: California; Juv.: juvenile 


\section{Common murre}

The presence of these deep-diving birds in 2000 was negatively associated with ocean depth, and although our top model suggested some weak support for a negative effect of pycnocline depth, the $95 \%$ CIs on the beta associated with this effect included zero. Thus, it added little in addition to the ocean depth effect (Table 4, Fig. 6). In 2002, this general relationship was reversed, with greater pycnocline depths associated with decreased probability of presence and only weak support for the negative effect of ocean depth (Table 5). In other words, murres were more closely related to the upwelling front in 2002 than in 2000.

Common murre density in 2000 was higher when SSS was increased and there was also some weak support for the negative effect of adult and subadult salmon, i.e. potential competitors, on murre density (Table 5). In 2002, pycnocline depth clearly had the strongest effect on density, but there was also weak support for the negative effect of thermocline slope (ThSlp) and the strong gradient of properties associated with the inshore side of Feature B (DistB; Table 5).

This species breeds in colonies along the adjacent coast, but unlike our findings in the initial analysis (Ainley et al. 2005), distance to nearest colony was not an important effect on either the presence or the density of murres.

\section{Cassin's auklet}

The presence of this mid-depth diving species was associated most strongly with maximum depth of chlorophyll in 2000, although both pycnocline depth and the density of large zooplankton were supported by our best model. The presence of Cassin's auklet increased with decreased chlorophyll maximum depth in 2000, with a similar relationship with pycnocline depth observed in 2002. In addition, in 2002, the probability of auklet presence was higher closer to
Table 5. Selection of top 5 models relating environmental and covariates to density of abundant seabirds during June and August 2000 and 2002, using Akaike's information criterion adjusted for small sample size $\left(\mathrm{AIC}_{\mathrm{c}}\right)$. The model deviance (DEV), number of parameters $(k), \Delta \mathrm{AIC}_{c}$, and $\mathrm{AIC}_{c}$ weights $\left(\mathrm{AIC}_{\mathrm{c}} \mathrm{wt}\right)$ are given for all models. The sign of the slope coefficients $(\beta)$ are included, with positive (+) and negative (-) signs denoting coefficients with $95 \%$ CIs that do not include zero; otherwise, sign denoted as zero. Slope signs listed in the order that coefficients appear in models. Intercept-only model is included for comparison. See covariate descriptions in Table 1

\begin{tabular}{|c|c|c|c|c|c|}
\hline Model & DEV & $k$ & $\Delta \mathrm{AIC}_{\mathrm{C}}{ }^{\mathrm{a}}$ & $\mathrm{AIC}_{\mathrm{c}} \mathrm{wt}$ & $\beta$ \\
\hline \multicolumn{6}{|l|}{ Black-footed albatross, 2000} \\
\hline GroupB, ZD_med & 178.11 & 5 & 0.00 & 0.37 &,+- \\
\hline GroupD, ZD_med & 178.61 & 5 & 0.50 & 0.29 &,+- \\
\hline GroupB & 182.76 & 4 & 2.29 & 0.12 & + \\
\hline GroupD & 183.15 & 4 & 2.68 & 0.10 & + \\
\hline GroupB, DistB & 182.26 & 5 & 4.15 & 0.05 &,+ 0 \\
\hline Intercept-only & 198.54 & 3 & 15.79 & 0.00 & \\
\hline \multicolumn{6}{|l|}{ Black-footed albatross, 2002} \\
\hline Pyc_dpt, MAX_dp & 281.22 & 5 & 0.00 & 0.20 &,- 0 \\
\hline Pyc_dpt & 283.55 & 4 & 0.10 & 0.19 & - \\
\hline DistB & 284.33 & 4 & 0.88 & 0.13 & - \\
\hline GroupA, MAX_dp & 282.71 & 5 & 1.49 & 0.10 &,+ 0 \\
\hline GroupA & 285.31 & 4 & 1.86 & 0.08 & + \\
\hline Intercept-only & 292.00 & 3 & 6.37 & 0.04 & \\
\hline \multicolumn{6}{|l|}{ Pink-footed shearwater, 2000} \\
\hline CHLMX & 189.28 & 4 & 0.00 & 0.62 & + \\
\hline DistB & 192.11 & 4 & 2.83 & 0.15 & - \\
\hline GroupA & 193.50 & 4 & 4.22 & 0.08 & + \\
\hline MAX_dp & 195.79 & 4 & 6.51 & 0.02 & - \\
\hline MLD & 196.46 & 4 & 7.18 & 0.02 & - \\
\hline Intercept-only & 199.77 & 3 & 8.23 & 0.01 & \\
\hline \multicolumn{6}{|l|}{ Pink-footed shearwater, 2002} \\
\hline GroupA & 222.56 & 4 & 0.00 & 0.59 & + \\
\hline Intercept-only & 229.97 & 3 & 5.14 & 0.05 & \\
\hline Cruise & 228.04 & 4 & 5.48 & 0.04 & 0 \\
\hline GroupE & 228.67 & 4 & 6.11 & 0.03 & 0 \\
\hline SSS & 228.92 & 4 & 6.35 & 0.02 & 0 \\
\hline GroupC & 229.10 & 4 & 6.54 & 0.02 & 0 \\
\hline \multicolumn{6}{|l|}{ Sooty shearwater, 2000} \\
\hline \multicolumn{6}{|l|}{ Cruise $^{\mathrm{b}}$, GroupA, } \\
\hline Cruise $\times$ GroupA & 919.46 & 6 & 0.00 & 0.48 &,,-+ 0 \\
\hline Cruise, GroupA & 922.41 & 5 & 0.85 & 0.31 &,-+ \\
\hline Cruise, ZD_lg & 926.73 & 5 & 5.16 & 0.04 &,- 0 \\
\hline Cruise, Fish & 927.65 & 5 & 6.08 & 0.02 & 0,0 \\
\hline ZD_lg, GroupA & 927.79 & 5 & 6.22 & 0.02 &,- 0 \\
\hline Intercept-only & 936.69 & 3 & 10.97 & 0.00 & \\
\hline \multicolumn{6}{|l|}{ Sooty shearwater, 2002} \\
\hline Cruise $^{\mathrm{b}}$, MAX_dp, Fish & 910.23 & 6 & 0.00 & 0.17 &,,--+ \\
\hline Cruise, MAX_dp, ZD_med & 910.27 & 6 & 0.04 & 0.17 &,,--+ \\
\hline Cruise, DPTH, Fish & 911.40 & 6 & 1.17 & 0.09 &,,-- 0 \\
\hline Cruise, DPTH, ZD_med & 911.61 & 6 & 1.39 & 0.09 & $-, 0,0$ \\
\hline Cruise, MAX_dp, DPTH & 912.05 & 6 & 1.82 & 0.07 & $-, 0,0$ \\
\hline Intercept-only & 927.21 & 3 & 10.74 & 0.00 & \\
\hline \multicolumn{6}{|c|}{ Fork-tailed storm-petrel, 2000} \\
\hline GroupB, DPTH & 126.68 & 4 & 0.00 & 0.33 &,+ 0 \\
\hline GroupD & 129.24 & 3 & 0.15 & 0.30 & + \\
\hline GroupB & 129.41 & 3 & 0.32 & 0.28 & + \\
\hline DPTH & 132.24 & 3 & 3.15 & 0.07 & + \\
\hline DistB $^{2}$ & 134.72 & 3 & 5.64 & 0.02 & + \\
\hline Intercept-only & 146.83 & 2 & 15.45 & 0.00 & \\
\hline
\end{tabular}


Table 5 (continued)

\begin{tabular}{|c|c|c|c|c|c|}
\hline Model & DEV & $k$ & $\Delta \mathrm{AIC}_{\mathrm{c}}{ }^{\mathrm{a}}$ & $\mathrm{AIC}_{\mathrm{c}} \mathrm{wt}$ & $\beta$ \\
\hline \multicolumn{6}{|l|}{ Fork-tailed storm-petrel, 2002} \\
\hline Pyc_dpt & 226.73 & 4 & 0.00 & 0.31 & - \\
\hline Pyc_dpt, DPTH & 224.67 & 5 & 0.32 & 0.26 &,- 0 \\
\hline DPTH & 228.68 & 4 & 1.95 & 0.12 & - \\
\hline DPTH, SST & 227.25 & 5 & 2.90 & 0.07 &,- 0 \\
\hline DPTH, DistB & 227.50 & 5 & 3.16 & 0.06 &,- 0 \\
\hline Intercept-only & 236.03 & 3 & 4.12 & 0.01 & \\
\hline \multicolumn{6}{|l|}{ Common murre, 2000} \\
\hline SSS & 362.53 & 4 & 0.00 & 0.37 & + \\
\hline SSS, GroupD & 361.60 & 5 & 1.28 & 0.20 &,+ 0 \\
\hline DistB & 365.18 & 4 & 2.65 & 0.10 & - \\
\hline GroupD & 365.95 & 4 & 3.42 & 0.07 & - \\
\hline DistB, GroupD & 363.80 & 5 & 3.49 & 0.06 & 0,0 \\
\hline Intercept-only & 372.06 & 3 & 7.37 & 0.01 & \\
\hline \multicolumn{6}{|l|}{ Common murre, 2002} \\
\hline Pyc_dpt, ThSlp & 431.06 & 5 & 0.00 & 0.41 &,- 0 \\
\hline Pyc_dpt & 433.77 & 4 & 0.55 & 0.31 & - \\
\hline Pyc_dpt, DistB & 432.73 & 5 & 1.68 & 0.18 &,- 0 \\
\hline ThSlp, DistB & 435.02 & 5 & 3.97 & 0.06 &,-- \\
\hline DistB & 439.36 & 4 & 6.14 & 0.02 & - \\
\hline Intercept-only & 450.75 & 3 & 15.40 & 0.00 & \\
\hline \multicolumn{6}{|l|}{ Cassin's auklet, 2000} \\
\hline DistB, GroupA & 155.91 & 5 & 0.00 & 0.46 & $0,-$ \\
\hline SST, GroupA & 158.49 & 5 & 2.59 & 0.13 &,- 0 \\
\hline SSS, GroupA & 159.71 & 5 & 3.81 & 0.07 &,+- \\
\hline SST & 162.18 & 5 & 3.82 & 0.07 & - \\
\hline DistB & 162.92 & 4 & 4.56 & 0.05 & - \\
\hline Intercept-only & 168.12 & 3 & 7.41 & 0.01 & \\
\hline \multicolumn{6}{|l|}{ Cassin's auklet, 2002} \\
\hline Cruise $^{\mathrm{c}}$ & 185.35 & 4 & 0.00 & 0.27 & + \\
\hline Cruise, GroupD & 183.74 & 5 & 0.85 & 0.18 &,+ 0 \\
\hline Cruise, GroupD, Cruise $\times$ GroupD & 182.16 & 6 & 1.85 & 0.11 & $+, 0,0$ \\
\hline Cruise, Pyc_dpt & 185.03 & 5 & 2.15 & 0.09 &,+ 0 \\
\hline Cruise, SSS & 185.05 & 5 & 2.16 & 0.09 &,+ 0 \\
\hline Intercept-only & 199.65 & 3 & 11.94 & 0.00 & \\
\hline \multicolumn{6}{|c|}{$\begin{array}{l}{ }^{\text {a }} \text { Lowest QIC for: Cassin's auklet in } 2000 \text { was } 167.21 \text { and in } 2002 \text { was } 194.22 \text {; } \\
\text { black-footed albatross in } 2000 \text { was } 189.16 \text { and in } 2002 \text { was } 291.89 \text {; common } \\
\text { murre in } 2000 \text { was } 370.94 \text { and in } 2002 \text { was } 441.54 \text {; pink-footed shearwater } \\
\text { in } 2000 \text { was } 197.94 \text { and in } 2002 \text { was } 231.20 \text {; sooty shearwater in } 2000 \text { was } \\
931.82 \text { and in } 2002 \text { was } 922.56 \text {; fork-tailed storm-petrel in } 2000 \text { was } 135.66 \\
\text { and in } 2002 \text { was } 235.46 \\
{ }^{b} \text { Bird density higher on } 1 \text { st cruise compared to } 2 \text { nd } \\
{ }^{c} \text { Bird density higher on } 2 \text { nd cruise compared to } 1 \text { st }\end{array}$} \\
\hline
\end{tabular}

densities recorded for the 2 nd cruise in August compared to the first cruise. There was also weak support for both an additive or interactive negative effect of demersal fish density on auklet density, but cruise had the strongest effect overall (Table 5). Demersal fish also would be competitors for zooplankton prey.

\section{Co-occurrence of seabirds}

The 2 most abundant species encountered (see Ainley et al. 2005) and the ones having the highest likelihood of competing for the same prey, owing to body size and subsurface foraging, i.e. the common murre and sooty shearwater, were negatively associated in foraging flocks (Table 6). The 2 shearwaters, however, with the sooty being 2 orders of magnitude more abundant than the pink-footed, were positively associated. The pink-footed is not a deep diver like the sooty but rather often catches prey on the wing, forced to the surface by subsurface foragers.

\section{DISCUSSION}

\section{Interannual differences in patterns}

The factors affecting seabird density vary by species and year, but some consistencies with previous work (Ainley et al. 2005) and between species and years are evident. With the addition of prey abundance data, while still impor- breeding colonies (Table 4, Fig. 7). The auklet is a much weaker and slower flyer than the murre (Spear \& Ainley 1997), which might explain the latter relationship.

When Cassin's auklets were present on transects in 2000, density was higher at locations inshore of Feature B (DistB), with weaker support for an additional association with lower densities of adult salmon, potential competitors (Table 5). In 2002, cruise had a very strong effect on auklets, with higher
Table 6. Results of analysis using Cole's index of association for all pairwise combinations of common murre, pink-footed shearwater, and sooty shearwater species. The symbols $(+)$ and $(-)$ respectively indicate that 2 species were more or less likely to be found together than would be expected if they were distributed randomly with respect to each other. ns: not significant

\begin{tabular}{|c|c|c|c|c|}
\hline Cruise & $\begin{array}{c}\text { Common } \\
\text { murre } \times \\
\text { Sooty } \\
\text { shearwater }\end{array}$ & $\begin{array}{c}\text { Common } \\
\text { murre } \times \\
\text { Pink-footed } \\
\text { shearwater }\end{array}$ & $\begin{array}{c}\text { Sooty } \\
\text { shearwater } \times \\
\text { Pink-footed } \\
\text { shearwater }\end{array}$ & Transects \\
\hline June 2000 & $(-) p<0.01$ & $\mathrm{~ns}$ & ns & 114 \\
\hline August 2000 & ns & ns & $(+) p<0.001$ & 79 \\
\hline June 2002 & $(-) p<0.001$ & $(-) p<0.05$ & (+) $p<0.01$ & 212 \\
\hline August 2002 & ns & ns $(+)$ & $p<0.1$ & 114 \\
\hline
\end{tabular}



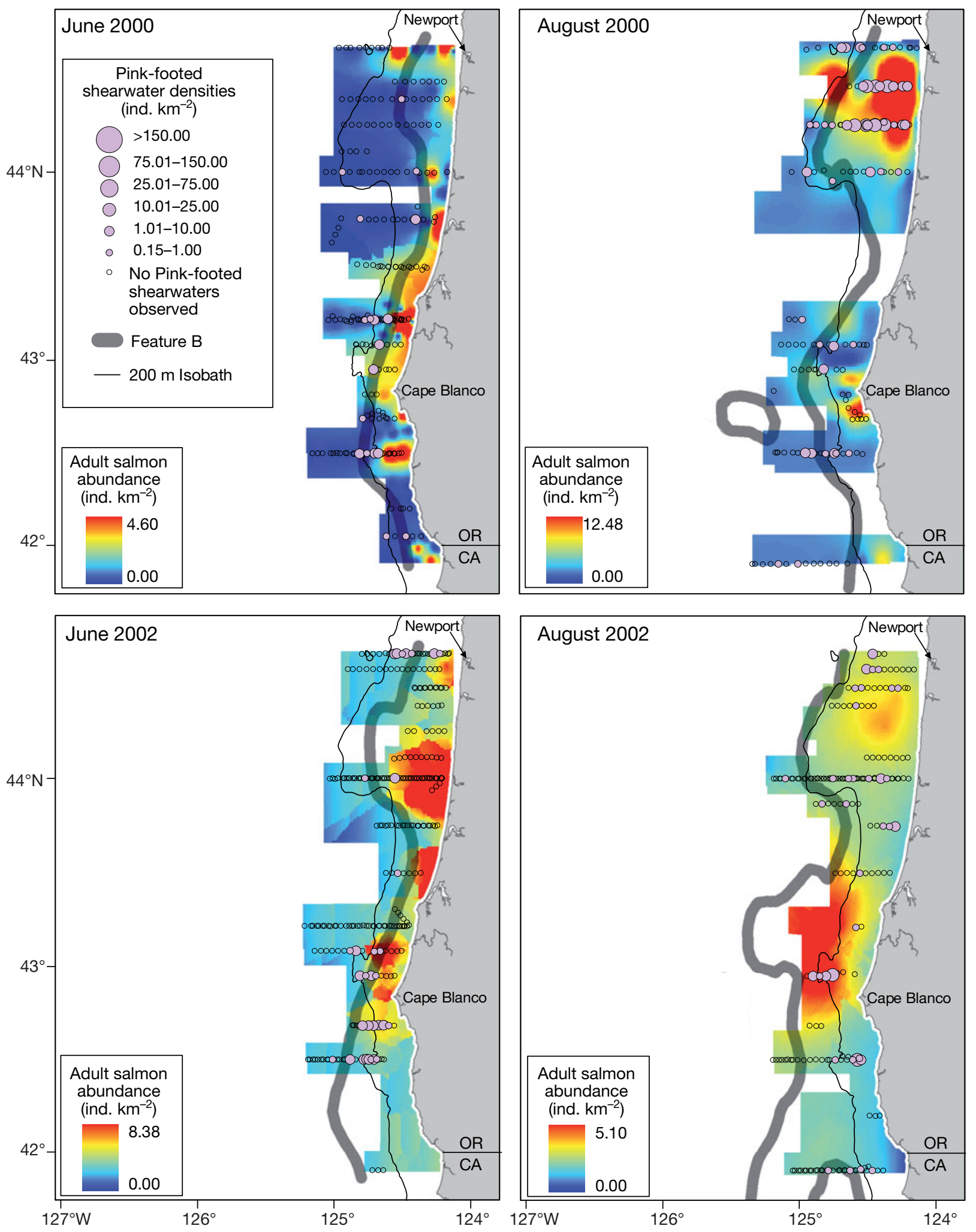

Fig. 3. Pink-footed shearwater occurrence patterns plotted as density in relation to covariate with strongest support based on model weights from density and presence-absence analyses (Tables 2, 4 \& 5). In 2000, shearwater presence was related to density of adult salmon (GroupA). In 2002, on transects where shearwater occurred, density was also related to adult salmon densities (GroupA). Feature B (upwelling front) is shown by the shaded thick line, and the shelfbreak (200 $\mathrm{m}$ isobath) by the thin black line. 

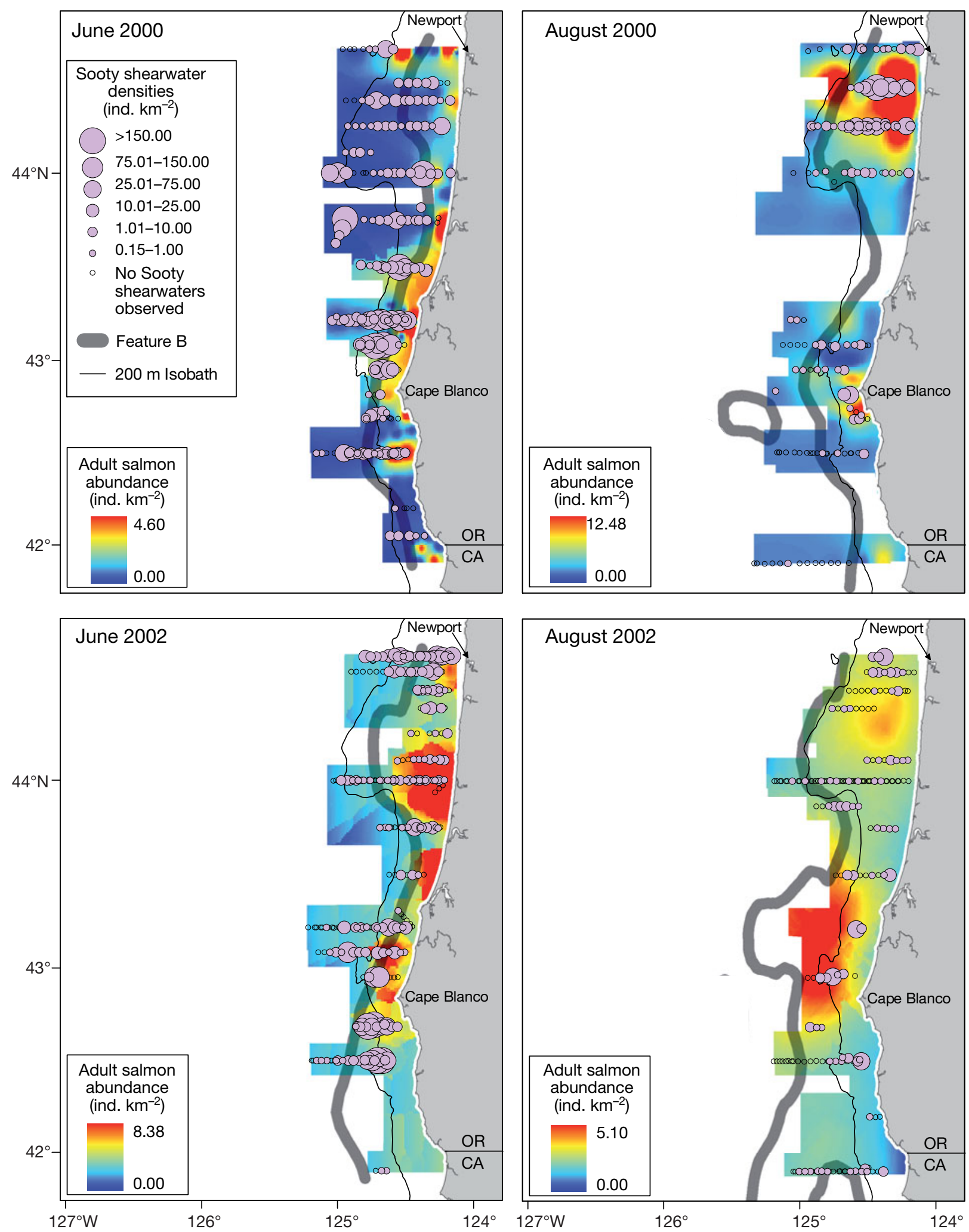

Fig. 4. Sooty shearwater occurrence patterns plotted as density in relation to covariate with strongest support based on model weights from both density and presence-absence analyses (Tables 2, 4 \& 5). Shearwater presence in 2000 and density on transects where birds were present in 2002 was related to density of adult salmon (GroupA). Feature B (upwelling front) is shown by the shaded thick line, and the shelfbreak (200 $\mathrm{m}$ isobath) by the thin black line. OR: Oregon; CA: California 

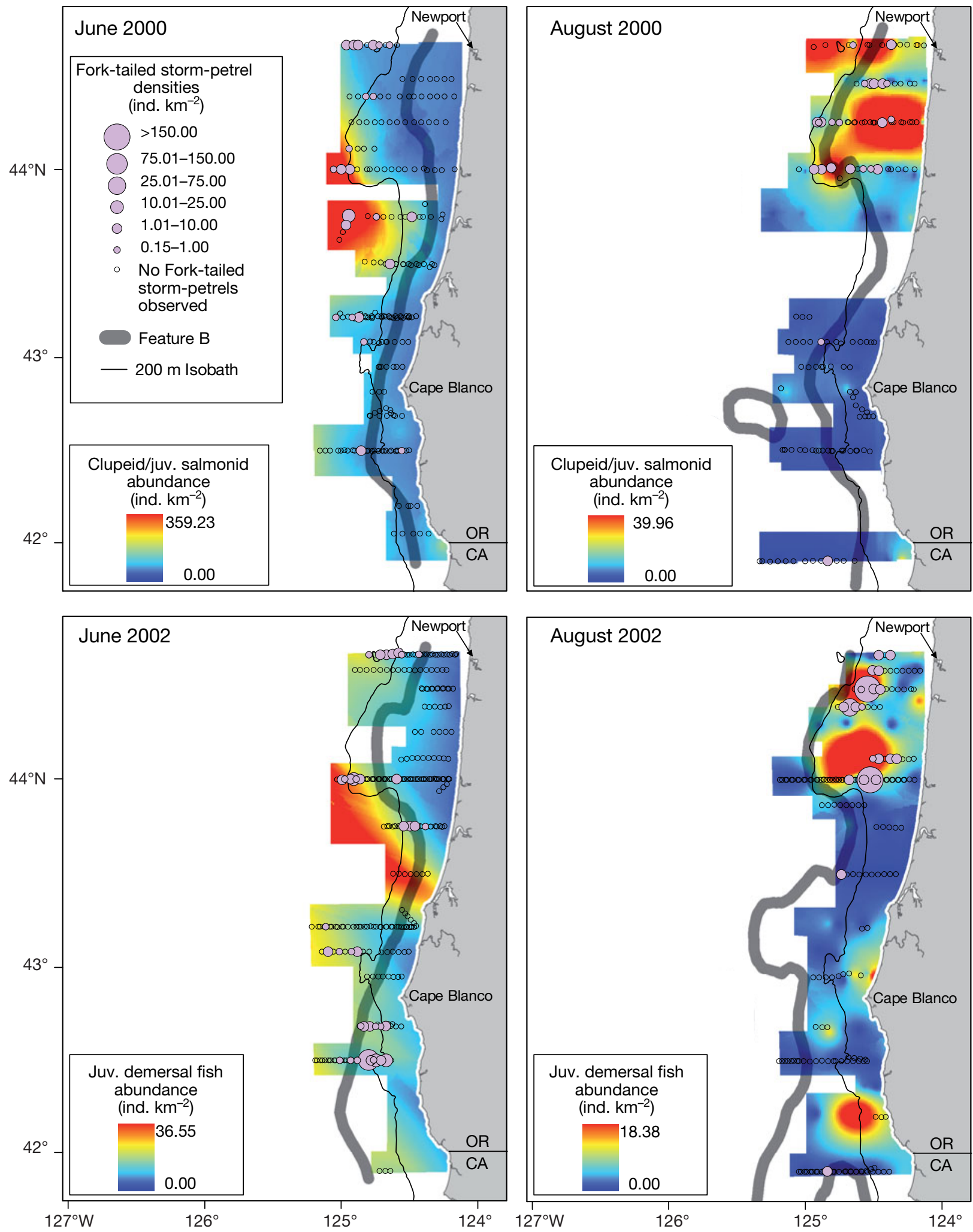

Fig. 5. Fork-tailed storm-petrel occurrence patterns plotted as density in relation to covariate with strongest support based on model weights from both density and presence-absence analyses (Tables 2, 4 \& 5). Storm-petrel presence related to density of small mid-water fish (GroupB) in 2000 and juvenile demersal fish (GroupD) in 2002. Feature B (upwelling front) is shown by the shaded thick line, and the shelfbreak (200 $\mathrm{m}$ isobath) by the thin black line. OR: Oregon; CA: California; Juv.: juvenile 

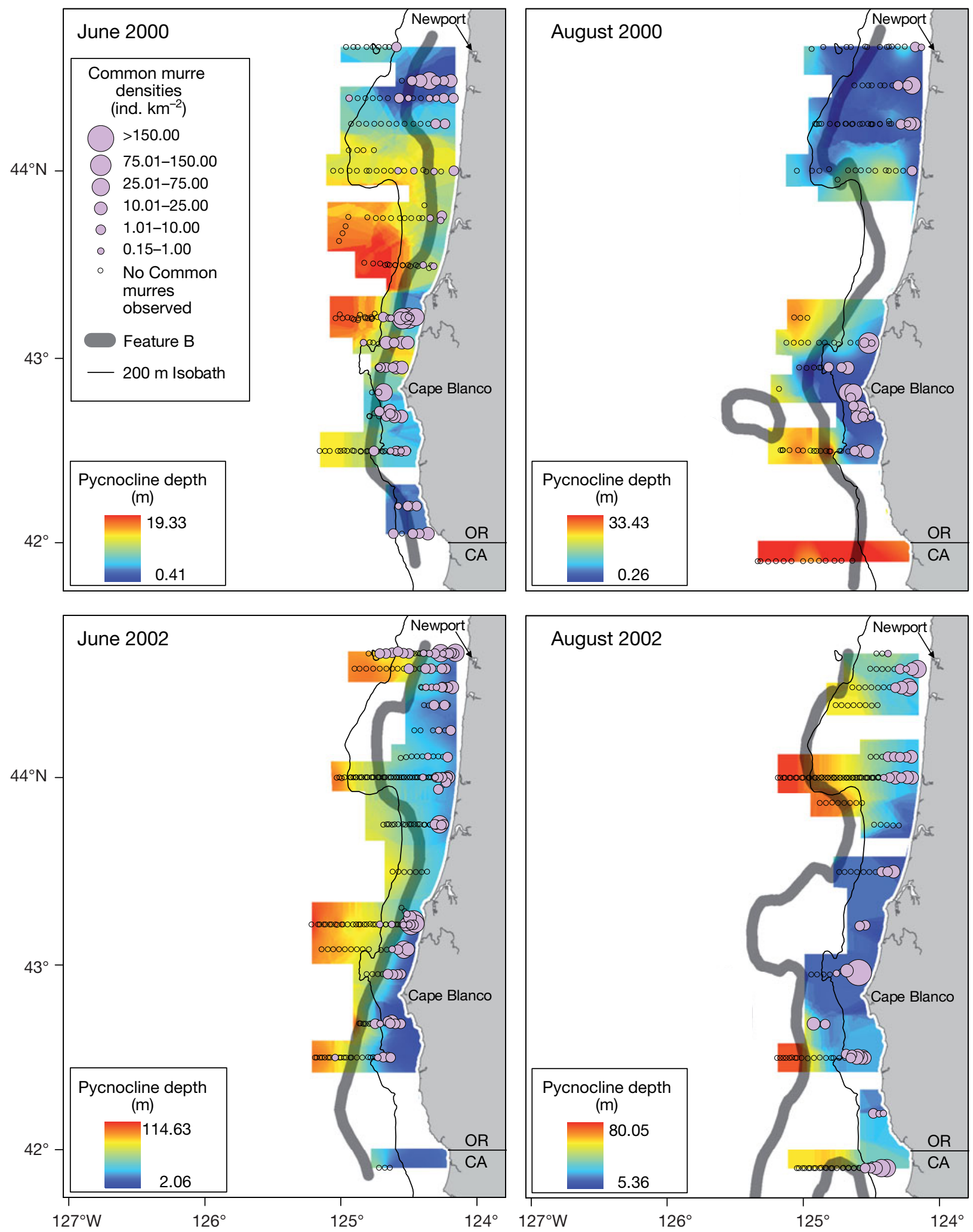

Fig. 6. Common murre occurrence patterns plotted as density in relation to covariate with strongest support based on model weights from both density and presence-absence analyses (Tables 2, 4 \& 5). On transects where murre were present, density was relative to pycnocline depth in both years. Feature B (upwelling front) is shown by the shaded thick line, and the shelfbreak (200 m isobath) by the thin black line. OR: Oregon; CA: California 

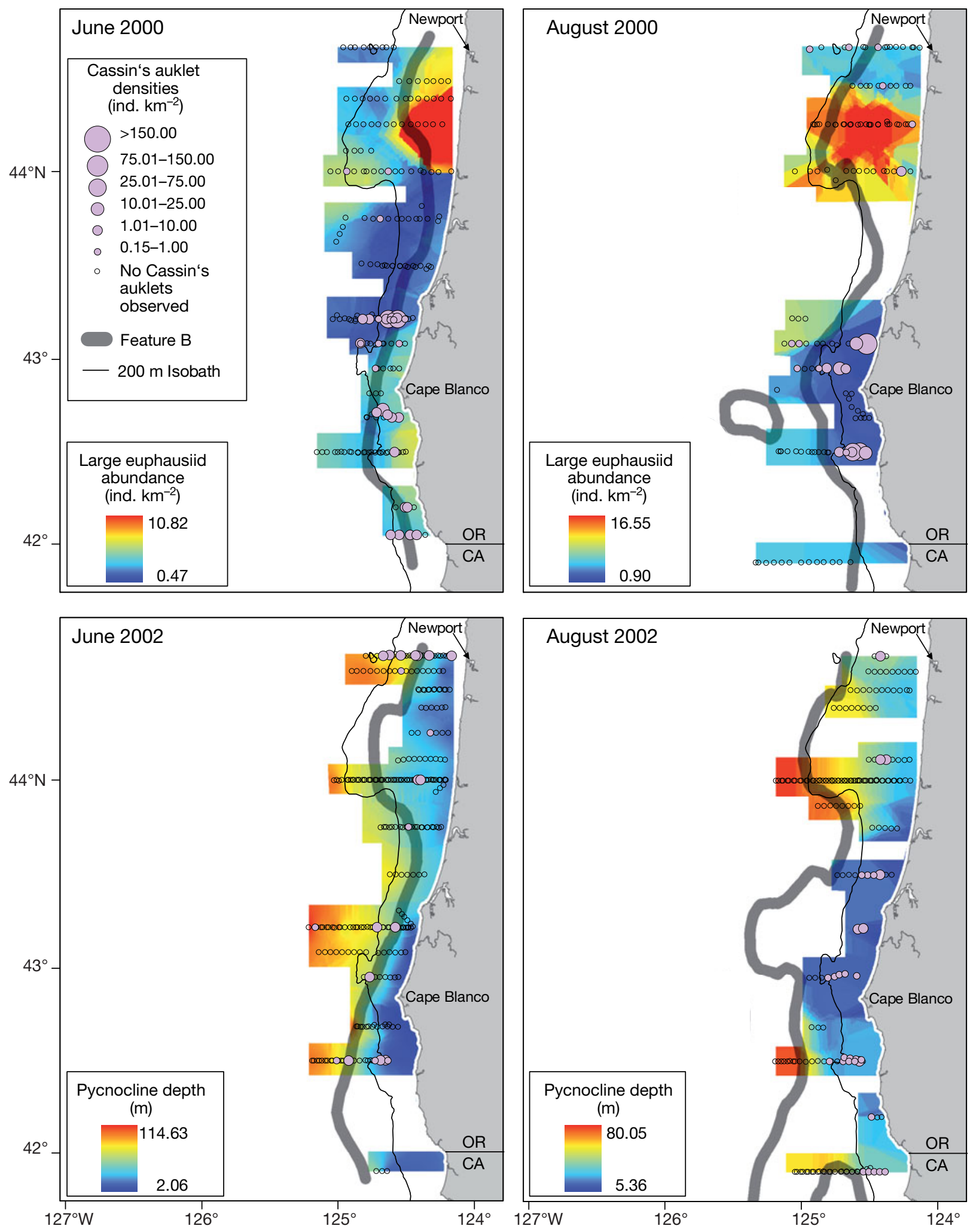

Fig. 7. Cassin's auklet occurrence patterns plotted as density across all transects in relation to covariate with strongest support based on model weights from both density and presence-absence analyses (Tables 2, 4 \& 5). Auklet presence in 2000 related to euphausiids (ZD_lg) in 2000 and to pycnocline depth in 2002. Feature B (upwelling front) is shown by the shaded thick line, and the shelfbreak (200 $\mathrm{m}$ isobath) by the thin black line. OR: Oregon; CA: California 
tant to some species, proximity to the upwelling front (DistB, DistB ${ }^{2}$ ) became less directly important than what was evident in the previous analysis, as we hypothesized. Pycnocline depth became the important proxy for the front. Although, again, less so than reported in Ainley et al. (2005), the chlorophyll maximum depth, another indirect measure of prey availability at the larger scale (as is location of a front), was important for a few species. Not surprisingly considering this effect, Reese \& Brodeur (2006) found that chlorophyll concentration was important in explaining patterns in fish occurrence in the study area. Thus, if chlorophyll maximum is a proxy for fish abundance, it is not surprising that this covariate declined somewhat in importance when direct measures of fish abundance were included. Nevertheless, the comments made by Ainley et al. (2005) in regard to birds being attracted, at the mesoscale and above, to areas of strong, biologically meaningful odor would still apply.

In general, we observed stronger effects of biotic, especially zooplankton and fish, covariates during 2000 than during 2002 (Table 7). The existence of this interannual difference is consistent with the large contrasts in ocean properties observed between years (Table 2) and consistent with annual variation in oceanographic measures of the NCC as noted by others (e.g. Wheeler et al. 2003, Suchman \& Brodeur 2005, Reese \& Brodeur 2006). Reese \& Brodeur (2006) observed decreased nekton density (but not biomass) in 2000 compared to 2002 and, accordingly, a much higher preponderance of fish occurred in the diet of juvenile coho salmon in 2002 than in 2000 (Brodeur et al. 2007). The latter is consistent with a more 'normal' seasonality (earlier peak abundance) in larval release that year (Auth \& Brodeur 2006). Similar to our measures of zooplankton density (Table 3), copepod abundance off Newport in 2002 was twice that of 2000
(Peterson \& Schwing 2003). Finally, all these factors were consistent with an 'anomalously high' southward transport of high-nutrient cold water into the study area from the subarctic in 2002, a quality that was lacking in 2000 (Kosro 2003). These differences in ocean features between years are aligned with our observation that bird prey (small fish, zooplankton) abundance was lower in 2000 compared to 2002, and are also likely responsible for the variation in the strength of this effect on bird densities between species and years. In other words, when prey were less abundant or available, the effect on explaining predator occurrence was stronger. In some respects, this is consistent with the studies of Piatt $(1987,1990)$, who found that prey density was important in explaining the degree of aggregation by foraging, diving seabirds.

\section{Predation, competition, or co-occurrence?}

For the micronekton-feeding (small fish, large zooplankton), shallow-diving shearwaters, their close positive association between themselves and with adult salmon (GroupA) likely reflects, at the least, the cooccurrence of predators seeking the same prey. On the other hand, the salmon could also be facilitating prey capture by the birds by concentrating prey or driving them closer to the surface, a well-known association of seabirds with subsurface predators in other systems (e.g. Safina \& Burger 1985, Harrison et al. 1991, Ballance et al. 1997). The negative relationship between adult salmon and the diminutive Cassin's auklet, both being planktivores especially on euphausiids, could indicate competition for the same prey. As pointed out by L. T. Ballance (pers. comm.), the auklet has far less aerial ability than the shearwater, and thus must interact directly and continuously in the water with the salmon.

Table 7. An interspecific comparison and summary of the variables most important to explain the occurrence patterns of respective predator species (see Tables 4 \& 5 for more details). Bold type emphasizes an organism or group of organisms; note preponderance of the latter factors during 2000 compared to 2002. See covariate description in Table 1

\begin{tabular}{|c|c|c|c|}
\hline & Model & 2000 & 2002 \\
\hline Black-footed albatross & $\begin{array}{c}\text { Presence-absence } \\
\text { Density }\end{array}$ & $\begin{array}{l}\text { GroupA, ZD_med } \\
\text { GroupB, ZD_med }\end{array}$ & $\begin{array}{c}\text { DistB }{ }^{2}, \text { SSS } \\
\text { Pyc_dpt, MAX_dp }\end{array}$ \\
\hline Pink-footed shearwater & $\begin{array}{c}\text { Presence-absence } \\
\text { Density }\end{array}$ & $\begin{array}{l}\text { GroupA, DPTH } \\
\text { CHLMX }\end{array}$ & $\begin{array}{l}\text { SSS, DPTH } \\
\text { GroupA }\end{array}$ \\
\hline Sooty shearwater & $\begin{array}{c}\text { Presence-absence } \\
\text { Density }\end{array}$ & $\begin{array}{l}\text { DPTH, GroupB } \\
\text { GroupA }\end{array}$ & $\begin{array}{l}\text { DPTH, CHLMX } \\
\text { MAX_dp, Fish }\end{array}$ \\
\hline Fork-tailed storm-petrel & $\begin{array}{c}\text { Presence-absence } \\
\text { Density }\end{array}$ & $\begin{array}{c}\text { SSS, GroupB } \\
\text { GroupB, DPTH }\end{array}$ & $\begin{array}{l}\text { GroupD } \\
\text { Pyc_dpt }\end{array}$ \\
\hline Common murre & $\begin{array}{c}\text { Presence-absence } \\
\text { Density }\end{array}$ & $\begin{array}{c}\text { DPTH, Pyc_dpt } \\
\text { SSS }\end{array}$ & $\begin{array}{l}\text { DPTH, Pyc_dpt } \\
\text { Pyc_dpt, ThSlp }\end{array}$ \\
\hline Cassin's auklet & $\begin{array}{c}\text { Presence-absence } \\
\text { Density }\end{array}$ & $\begin{array}{c}\text { Pyc_dpt, MAX_dp, ZD_lg } \\
\text { DistB, GroupA }\end{array}$ & $\begin{array}{c}\text { Pyc_dpt, ColDist } \\
\text { Cruise }\end{array}$ \\
\hline
\end{tabular}


Similarly, both salmon (Reese \& Brodeur 2006) and murres (the present study; see also Ainley et al. 2005) respond very similarly to SST, SSS, and other measures indicating spatially and temporally close association with the inshore upwelling front. This is consistent with finding no relationship to the occurrence of adult sardines and saury (GroupE), which in the NCC occur offshore, in highly stratified (deep pycnocline and thermocline) warm waters (Emmett et al. 2005).

The fact that small fish and zooplankton were less abundant in 2000, with a stronger effect, therefore, on predator occurrence, might lead to other implications of ecological relationships. In 2002, when small fish were far more abundant overall, and likely not limiting to most piscivores, the physical features did a better job of 'explaining' the birds' patterns. In other words, the predators needed just to be in the general vicinity of easily available food to be able to find prey, and not as densely aggregated to therefore facilitate closer statistical coincidence (cf. Piatt 1990). Regardless, especially sooty shearwaters and common murres, by far the 2 most abundant avian piscivores in the NCC, did not mix in foraging flocks (Hoffman et al. 1981, Ainley \& Boekelheide 1990). Murre flocks tended to occur inshore of sooty shearwater flocks, suggesting possible segregation in foraging but within the same mesoscale habitat (at least as we measured it; see also Wiens \& Scott 1975, Ainley et al. 2005). Where they did cooccur, they avoided foraging in the same flocks. This is further indirect evidence that these piscivores, likely with help from other predators (see next paragraph), can negatively affect the availability of prey for one another in this system (see also Logerwell \& Hargreaves 1996, Lewis et al. 2001, Ainley et al. 2003). These results at face value appear to be contrary to those of Ballance et al. (1997), who found that largebodied seabirds in the tropics, only under conditions of high food availability, physically excluded smaller species from foraging flocks and hypothesized that under those conditions, competition had a large role in community structuring. Trophic competition, and flock exclusion appears important too, in the NCC even when food availability is low. In the habitat separation within the NCC, as discussed above, the species are of similar body size.

The present results in part, then, merely confirm long-held, local knowledge that smaller fishes, especially anchovies, are the food of choice for murres, shearwaters, and many marine fishes in the central and northern NCC during mid- to late summer (Chu 1984, Ainley et al. 1996, Miller \& Brodeur 2007). Humpback whales Megaptera novaeangliae, another predator of anchovies and other fish of inshore, upwelled waters, were associated with adult salmon as well in our study area and, of course, would also have been involved in any prey depletion (Tynan et al. 2005). On the other hand, associations of whales, birds, and predatory fish can result in coordinated foraging behavior as fish prey are 'balled-up', presumably facilitating the micro-scale foraging by all predators involved (e.g. Robinson \& Tetley 2007).

\section{Spatial aspects of co-occurrence in food-web modeling}

Despite finding relationships between fish abundance and bird densities in the present study, we measured an inconsistent signal between food resources and seabird densities. There are a variety of reasons why this might be, including discordance between food abundance (as measured by us) and food availability (as perceived by the predator), the spatial scale at which we sample fish and at which fish are available to birds, and the influences of other fish predators on food availability for the avian species we studied. Most importantly, we found the closest relationship between predators and prey in the year when prey were less abundant and seemingly more patchy (see also Fauchald \& Erikstad 2002).

Obviously, further information is needed on the depth stratification of predators and prey, as well as their spatio-temporal ambits, in the waters of the NCC and elsewhere. This is especially true given the great mobility of the predators treated in a study such as ours (e.g. Inchausti \& Ballesteros 2008). The most successful models someday will use the ambits of the various species, rather than merely using densities in grid cells and depth bins (e.g. Brand et al. 2007). Trying to quantify the daily (or longer) spatio-temporal aspects of foraging by a whale, a school of salmon, and a shearwater flock within the same meso- to small-scale region would be an interesting study, and became only recently possible to resolve in this age of advanced electronic and acoustic tracking technology (e.g. Weimerskirch 2007, Au \& Benoit-Bird 2008).

Other evidence that the meso- and larger-scale spatial aspect to trophic transfer is not as simple as it might first appear is contained in the fish community hotspots identified in the GLOBEC study area by Reese \& Brodeur (2006, their Fig. 4). While the Heceta Bank and Crescent City hotspots for fish, especially for salmon, were certainly attractive to whales (cf. Tynan et al. 2005, their Fig. 5), there was no 1:1 match in the case of birds (cf. Ainley et al. 2005, their Fig. 2). A whale and bird hotspot (juvenile salmon, too) was located at the base of the upwelling plume that extended out from Cape Blanco (midway in the study area). This was an area of particularly dense concentrations of euphausiids (e.g. Ressler et al. 2005) but apparently not fish. Per- 
haps this represents still another prey-depletion case by predators, with fish likely being the most important euphausiid predators in this region (cf. Scheffer et al. 2005, Miller \& Brodeur 2007). From the perspective of the entire study area, the concentrations of murres and shearwaters were found on the inshore edges, rather than throughout the entire expanse of the fish hotspots (cf. Reese \& Brodeur 2006, their Fig. 4; Ainley et al. 2005, their Fig. 2). This area of overlap coincided with the steep gradients in properties of the upwelling jet. Seemingly, forage fish were more vulnerable at least to avian, cetacean, and piscine (adult salmon) predation in that situation, and/or forage depletion by predators occurred at the edge of the prey 'hotspot' (e.g. Logerwell \& Hargreaves 1996). All of the bird species (as well as the whales or salmon) we considered here, except for perhaps breeding Cassin's auklets, could easily forage anywhere within the study area.

Trophic overlap as well as species co-occurrence are aspects of some of these species' interactions. While at the broadest scales, knowing population size, diet, and trophic transfer rates of these mobile predators and prey might bring valid, instructive outcomes to foodweb or ecosystem models, at the mesoscale and finer scales where the main interactions actually occur, we have a long way to go before finding satisfactory outputs. Better understanding of organism ambits and foraging behavior is important. Such information is necessary in models to understand the mechanisms behind the way in which climate change and fish extraction affect coastal marine ecosystems (e.g. Trites et al. 1999, Brand et al. 2007).

Acknowledgements. This paper is dedicated to the memory of M. Newcomer and L. Spear, who were key components of our cruise effort but who are no longer with us. We thank the entire NEP GLOBEC study group, and its steering committee for welcoming our participation and providing stimulating discussion at numerous workshops and meetings. The captains and crews of FV 'Frosti', FV 'Sea Eagle', RV 'New Horizon', RV 'Roger Revelle', RV 'Thomas B. Thompson', and RV 'Wecoma' were indispensible, as was the help in data collection provided by C. Alexander, R. Emmett, J. Fisher, J. Hodder, T. Miller, J. P. Noskov, S. Pool, and T. Pusser. Financial support was provided by National Science Foundation Grants OCE-0001035, OCE0435619, OCE-0534609; and National Oceanic and Atmospheric Administration (NOAA)/ Woods Hole Oceanographic Institution-CICOR Grant NA17RJ1223, and well as direct NOAA support of R.D.B. and D.C.R. L. Ballance, J. Piatt, and 2 anonymous reviewers kindly provided valuable comments to improve the manuscript. This is Contribution Number 621 of the US GLOBEC program.

\section{LITERATURE CITED}

Ainley DG, Boekelheide RJ (eds) (1990) Seabirds of the Farallon Islands: ecology, structure and dynamics of an upwelling system community. Stanford University Press, Palo Alto, CA
Ainley DG, Sanger GA (1979) Trophic relationships of seabirds in the northeastern Pacific Ocean and Bering Sea. In: Bartonek JC, Nettleship DN (eds) Conservation of seabirds in western North America. US Fish Wildl Serv Wildl Res Rep 11:95-122

Ainley DG, Spear LB, Allen SG (1996) Temporal and spatial variation in the diet of the common murre in California. Condor 98:691-705

Ainley DG, Ford RG, Brown ED, Suryan RM, Irons DB (2003) Prey availability, interference competition, and the geographic structure of seabird colonies: a study of blacklegged kittiwakes and forage fish in Prince William Sound, Alaska. Ecology 84:709-723

Ainley DG, Spear LB, Tynan CT, Barth JA, Cowles TJ, Pierce SD (2005) Factors affecting occurrence patterns of seabirds in the northern California Current, spring and summer 2000. Deep-Sea Res II 52:123-143

Alonzo SH (2002) State-dependent habitat selection games between predators and prey: the importance of behavioural interactions and expected lifetime reproductive success. Evol Ecol Res 4:759-778

> Alonzo SH, Switzer PV, Mangel M (2003) Ecological games in space and time: the distribution and abundance of Antarctic krill and penguins. Ecology 84:1598-1607

> Au WWL, Benoit-Bird KJ (2008) Broadband backscatter from individual Hawaiian mesopelagic boundary community animals with implications for spinner dolphin foraging. J Acoust Soc Am 123:2884-2894

Auth TD, Brodeur RD (2006) Distribution and community structure of ichthyoplankton off the coast of Oregon, USA, in 2000 and 2002. Mar Ecol Prog Ser 319:199-213

Ballance LT, Pitman RL, Reilly SB (1997) Seabird community structure along a productivity gradient: importance of competition and energetic constraint. Ecology 78: 1502-1518

Barth JA, Pierce SD, Smith RL (2000) A separating coastal upwelling jet at Cape Blanco, Oregon and its connection to the California Current System. Deep-Sea Res II 47: $783-810$

Barth JA, Pierce SD, Cowles TJ (2005) Mesoscale structure and its seasonal evolution in the northern California Current System. Deep-Sea Res II 52:5-28

Batchelder HP, Barth JA, Kosro MP, Strub PT and others (2002) The GLOBEC Northeast Pacific California Current System Program. Oceanography 15:36-47

- Batchelder HP, Strub PT, Lessard EJ, Weingartner TJ (2005) US GLOBEC biological and physical studies of plankton, fish and higher trophic level production, distribution, and variability in the northeast Pacific. Deep-Sea Res II 52:1-4

Brand EJ, Kaplan IC, Harvey CJ, Levin PS, Fulton EA, Hermann AJ, Field JC (2007) A spatially explicit ecosystem model of the California Current's food web and oceanography. US Dept Commerce, NOAA Tech Memo NMFSNWFSC-84

Briggs KT, Chu EW (1987) Trophic relationships and food requirements of California seabirds: updating models of trophic impact. In: Croxall JP (ed) Seabirds: feeding ecology and role in marine ecosystems. Cambridge University Press, Cambridge, p 279-304

Brodeur RD, Fisher JP, Teel DL, Emmett RL, Casillas E, Miller TW (2004) Juvenile salmonid distribution, growth, condition, origin and environmental and species associations in the Northern California Current. Fish Bull US 102:25-46 > Brodeur RD, Fisher JP, Emmett RL, Morgan CA, Casillas E (2005) Species composition and community structure of pelagic nekton off Oregon and Washington under variable oceanographic conditions. Mar Ecol Prog Ser 298:41-57 
Brodeur RD, Daly EA, Schabetsberger RA, Mier KL (2007) Interannual and interdecadal variability in juvenile coho salmon diets in relation to environmental changes in the Northern California Current. Fish Oceanogr 16:395-408

Burnham KP, Anderson DR (2002) Model selection and multimodel inference: a practical information-theoretic approach, 2nd edn. Springer-Verlag, New York

Chu EW (1984) Sooty shearwaters off California: diet and energy gain. In: Nettleship DN, Sanger GA, Springer PF (eds) Marine birds: their feeding ecology and commercial fisheries relationships. Canadian Wildlife Service, Dartmouth, NS, p 64-71

Cole LC (1949) The measurement of interspecific association. Ecology 30:411-424

Cooch E, White GC (2006) Program MARK: a gentle introduction, 4th edn. Available at www.phidot.org/softeware/ mark/docs/book/

Cunningham RB, Lindenmayer DB (2005) Modelling count data of rare species: some statistical issues. Ecology 86: 1135-1142

Dobbie MJ, Welsh AH (2001) Modelling correlated zeroinflated count data. Aust NZ J Stat 43:431-444

Emmett RL, Brodeur RD, Miller TW, Pool SS, Krutzikowsky GK, Bentley PJ, McCrae J (2005) Pacific sardine (Sardinops sagax) abundance, distribution, and ecological relationships in the Pacific Northwest. Calif Coop Ocean Fish Invest Rep 46:122-143

Fauchald P, Erikstad KE (2002) Scale-dependent predatorprey interactions: the aggregative response of seabirds to prey under variable prey abundance and patchiness. Mar Ecol Prog Ser 231:279-291

Fauchald P, Erikstad KE, Skarsfjord H (2000) Scale-dependent predator-prey interactions: the hierarchical spatial distribution of seabirds and prey. Ecology 81:773-783

Field JC, Francis RC, Aydin KY (2006) Top-down and bottomup dynamics: linking a fisheries-based ecosystem model with climate hypotheses in the Northern California Current. Prog Oceanogr 68:238-270

Fiksen Ø, Eliassen S, Titelman J (2005) Multiple predators in the pelagic: modelling behavioural cascades. J Anim Ecol 74:423-429

Fletcher D, MacKenzie D, Villouta E (2005) Modelling skewed data with many zeros: a simple approach combining ordinary and logistic regression. Environ Ecol Stat 12: 45-54

Foote KG, Stanton TK (2000) Acoustical methods. In: Harris R, Wiebe P, Lenz J, Skjoldal HR, Huntley M (eds) ICES zooplankton methodology manual. Academic Press, London, p 223-258

Gotelli NJ (2000) Null model analysis of species co-occurrence patterns. Ecology 81:2606-2621

Greene CH, Wiebe PH, Pershing AJ, Gal G and others (1998) Assessing the distribution and abundance of zooplankton: a comparison of acoustic and net-sampling methods with D-BAD MOCNESS. Deep-Sea Res II 45:1219-1237

Greenlaw CF (1979) Acoustical estimation of zooplankton populations. Limnol Oceanogr 24:226-242

Harrison NM, Whitehouse MJ, Heinemann D, Prince PA, Hunt GL Jr, Veit RR (1991) Observations of multispecies seabird flocks around South Georgia. Auk 108:801-810

Hoefer CJ (2000) Marine bird attraction to thermal fronts in the California Current system. Condor 102:423-427

Hoffman W, Heinemann D, Wiens JA (1981) The ecology of seabird feeding flocks in Alaska. Auk 98:437-456

- Inchausti P, Ballesteros S (2008) Intuition, functional responses and the formulation of predator-prey models when there is a large disparity in the spatial domains of the interacting species. J Anim Ecol 77:891-897
Johnston K, Ver Hoef JM, Krivoruchko K, Lucas N (2001) Using ArcGIS Geostatistical Analyst. ESRI, Redlands, CA Kosro PM (2003) Enhanced southward flow over the Oregon shelf in 2002: a conduit for subarctic water. Geophys Res Lett 30:8023, doi:10.1029/2003GL017936

Kundu PK, Allen JS (1976) Some three-dimensional characteristics of low frequency current fluctuations near the Oregon coast. J Phys Oceanogr 6:181-199

Lewis S, Sherratt TN, Hamer KC, Wanless S (2001) Evidence of intra-specic competition for food in a pelagic seabird. Nature 412:816-819

> Lima SL (2002) Putting predators back into behavioral predator-prey interactions. Trends Ecol Evol 17:70-75

- Lima SL, Dill LM (1990) Behavioral decisions made under the risk of predation: a review and prospectus. Can J Zool 68:619-640

Littell RC, Stroup WW, Freund RJ (2002) SAS for linear models, 4 th edn. SAS Institute, Cary, NC

> Logerwell EA, Hargreaves NB (1996) The distribution of sea birds relative to their fish prey off Vancouver Island: opposing results at large and small spatial scales. Fish Oceanogr 5:163-175

> Logerwell EA, Hewitt RP, Demer DA (1998) Scale-dependent spatial variance patterns and correlations of seabirds and prey in the southeastern Bering Sea as revealed by spectral analysis. Ecography 21:212-223

> Love RH (1971) Dorsal-aspect target strength of an individual fish. J Acoust Soc Am 49:816-823

Miller TW, Brodeur RD (2007) Diets of and trophic relationships among dominant marine nekton within the Northern California Current ecosystem. Fish Bull (Wash DC) 105: 548-559

Pan W (2001) Akaike's information criterion in generalized estimating equations. Biometrics 57:120-125

Peterson WT, Schwing FB (2003) A new climate regime in northeast Pacific ecosystems. Geophys Res Lett 30:1896, doi:10.1029/2003GL017528

Piatt JF (1987) Behavioural ecology of common murre and Atlantic puffin predation on capelin: implications for population biology. PhD thesis, Memorial University, St. John's, NL

Piatt JF (1990) The aggregative response of common murres and Atlantic puffins to schools of capelin. Stud Avian Biol 14:36-51

> Pinaud D, Weimerskirch H (2005) Scale-dependent habitat use in a long-ranging central place predator. J Anim Ecol 74:852-863

> Pinaud D, Weimerskirch H (2007) At-sea distribution and scale-dependent foraging behaviour of petrels and albatrosses: a comparative study. J Anim Ecol 76:9-19

Pollard R (1986) Frontal surveys with a towed profiling conductivity/temperature/depth measurement package (SeaSoar). Nature 323:433-435

Reese DC, Brodeur RD (2006) Identifying and characterizing biological hotspots in the northern California Current. Deep-Sea Res II 53:291-314

Reid JL, Mantyla AW (1976) The effect of geostrophic flow upon coastal sea elevations in the northern North Pacific Ocean. J Geophys Res 81:3100-3110

Ressler PH, Brodeur RD, Peterson WT, Pierce SD, Vance PM, Røstad AR, Barth JA (2005) The spatial distribution of euphausiid aggregations in the northern California Current during August 2000. Deep-Sea Res II 52:89-108

> Robinson KP, Tetley MJ (2007) Behavioural observations of foraging minke whales (Balaenoptera acutorostrata) in the outer Moray Firth, north-east Scotland. J Mar Biol Assoc UK 87:85-86 
Ruzicka JJ, Brodeur RD, Wainwright TC (2007) Seasonal food web models for the Oregon inner-shelf ecosystem: investigating the role of large jellyfish. Calif Coop Ocean Fish Invest Rep 48:106-128

Safina C, Burger J (1985) Common tern foraging: seasonal trends in prey fish densities and competition with bluefish. Ecology 66:1457-1463

Scheffer M, Carpenter S, De Young B (2005) Cascading effects of overfishing marine systems. Trends Ecol Evol 20: $579-581$

Soulé ME, Estes JA, Miller B, Honnold DL (2005) Strongly interacting species: conservation policy, management, and ethics. BioScience 55:168-176

Spear LB, Ainley DG (1997) Flight speed of seabirds in relation to wind speed and direction. Ibis 139:234-251

Spear L, Nur N, Ainley DG (1992) Estimating absolute densities off flying seabirds using analyses of relative movement. Auk 109:385-389

Spear LB, Ainley DG, Hardesty BD, Howell SNG, Webb SW (2004) Reducing biases affecting at-sea surveys of seabirds: use of multiple observer teams. Mar Ornithol 32: $147-157$

Editorial responsibility: John Piatt, Anchorage, Alaska, USA
Stanton TK, Wiebe PH, Chu D, Benfield MC, Scanlon L, Martin L, Eastwood RL (1994) On acoustic estimates of zooplankton biomass. ICES J Mar Sci 51:505-512

> Suchman CL, Brodeur RD (2005) Abundance and distribution of large medusae in surface waters of the northern California Current. Deep-Sea Res II 52:51-72

Trites AW, Livingston PA, Vasconcellos MC, Mackinson S, Springer AM, Pauly D (1999) Ecosystem change and the decline of marine mammals in the Eastern Bering Sea: testing the ecosystem shift and commercial whaling hypotheses. Fish Cent Res Rep 7:1-106

Tynan CT, Ainley DG, Barth JA, Cowles TJ, Pierce SD, Spear LB (2005) Cetacean association with hydrographic features in the northern California Current System. Deep-Sea Res II 52:145-167

- Weimerskirch H (2007) Are seabirds foraging for unpredictable resources? Deep-Sea Res II 54:211-223

Wheeler PA, Huyer A, Fleischbein J (2003) Cold halocline, increased nutrients and higher chlorophyll off Oregon in 2002. Geophys Res Lett 30:8021 doi:10.1029/ 2003GL017395

Wiens JA, Scott JM (1975) Model estimation of energy flow in Oregon coastal seabird populations. Condor 77:439-452

Submitted: October 1, 2008; Accepted: May 27, 2009

Proofs received from author(s): August 20, 2009 